\title{
The assessment of clinical competence in high stakes examinations: are we justified in abandoning old methods in favour of the new ?
}

Citation for published version (APA):

Wass, V. (2006). The assessment of clinical competence in high stakes examinations: are we justified in abandoning old methods in favour of the new ? [Doctoral Thesis, Maastricht University]. https://doi.org/10.26481/dis.20060512vw

Document status and date:

Published: 01/01/2006

DOI:

10.26481/dis.20060512vw

Document Version:

Publisher's PDF, also known as Version of record

Please check the document version of this publication:

- A submitted manuscript is the version of the article upon submission and before peer-review. There can be important differences between the submitted version and the official published version of record.

People interested in the research are advised to contact the author for the final version of the publication, or visit the DOI to the publisher's website.

- The final author version and the galley proof are versions of the publication after peer review.

- The final published version features the final layout of the paper including the volume, issue and page numbers.

Link to publication

\footnotetext{
General rights rights.

- You may freely distribute the URL identifying the publication in the public portal. please follow below link for the End User Agreement:

www.umlib.nl/taverne-license

Take down policy

If you believe that this document breaches copyright please contact us at:

repository@maastrichtuniversity.nl

providing details and we will investigate your claim.
}

Copyright and moral rights for the publications made accessible in the public portal are retained by the authors and/or other copyright owners and it is a condition of accessing publications that users recognise and abide by the legal requirements associated with these

- Users may download and print one copy of any publication from the public portal for the purpose of private study or research.

- You may not further distribute the material or use it for any profit-making activity or commercial gain

If the publication is distributed under the terms of Article $25 \mathrm{fa}$ of the Dutch Copyright Act, indicated by the "Taverne" license above, 
The assessment of clinical competence in high stakes examinations 
ISBN 10:9052785236

ISBN 13:9789052785233

Copyright Valerie I Wass, Manchester 2006

Lay-out and printing: Datawyse / Universitaire Pers Maastricht 


\title{
THE ASSESSMENT OF CLINICAL COMPETENCE IN HIGH STAKES EXAMINATIONS
}

\author{
ARE WE JUSTIFIED IN ABANDONING \\ OLD METHODS IN FAVOUR OF THE NEW?
}

\section{PROEFSCHRIFT}

ter verkrijging van de graad van doctor aan de Universiteit Maasticht, op gezag van de Rector Magnificus, Prof.mr. G.P.M.F. Mols, volgens het besluat van het College van Decanen

in het openbat te verdedigen op vrijdag 12 mei 2006 om 12.00 uur

door

Valerie I WASS

geboren op 14 februari Windsor, Berkshire, UK

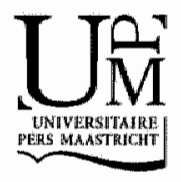




\section{Promotor}

Prof.dr. C.P.M. van der Vleuten

\section{Ca-promotor}

Dr. L.W.T. Schuwirth

\section{Beoordelingscommissie}

Prof.dr. A. Scherploier (voorzitter)

Prof.dr. E. Heineman

Dr. $Y$. van Leeuwen

Prof. P. ONeill, University of Manchester, UK

Prof. Dame L. Southgate, Uniwersity of London, UK 
For my parents whose unfailing love and support over the years has been beyond measure and with thanks to Katherine, Sam and Naomi for their patience and understanding. 



\section{Contents}

1 untroduction

2 The assessment of clinical competence

Published in: Lancet 2001; 357:945-49

3 Composite undergraduate clinical examinations:

How should the components be combined to maximise relliability?

Published in: Medical Education 2001; 35:326 - 30

4 Standardised or real patients to test clinical competence?

The long case revisited.

Published in: Medicall Education 2001: 35:321-25

5 Does observation add to the validity of the long case?

Published in: Medical Education 2001; 35:729-34

6 Achieving acceptable reliability in oral examinations: an analysis of the Royal College of General Practitioners Membership Examination's Oral Component.. Published in: Medical Education 2003; 37:126-31

7 Performance differences of medical students from ethnic minorities ir a final medical school Objective Structured Clinical Examination: is there potential for bias in communication skills testing?

Published in: British Medical Journal, 2003; 326:800-3

8 Discussion

Summary

Samenvatting 


\section{Abbreviations}

$\begin{array}{ll}\text { DOH } & \text { Department of Health } \\ \text { EM } & \text { Ethnic Minority } \\ \text { EMQ } & \text { Extended Matching Question } \\ \text { GMC } & \text { General Medical Council } \\ \text { HT } & \text { History Taking } \\ \text { MCQ } & \text { Multiple Choice Question } \\ \text { MRCGP } & \text { Membership of the Royal College of General Practitioners } \\ \text { NHS } & \text { National Health Service } \\ \text { OSCE } & \text { Objective Structured Clinical Examination } \\ \text { OSLER } & \text { Objective Structured Long Examination Record } \\ \text { RCGP } & \text { Royal College of General Practitioners } \\ \text { SAQ } & \text { Short Answer Question } \\ \text { SEM } & \text { Standard Error of Measurement } \\ \text { SP } & \text { Simulated Patient } \\ \text { WM } & \text { White Majority }\end{array}$


\%

Introduction 
The American educationalist Flexner (1910) stated: "There is only one sort of licensing test that is significant. a test that ascertains the practical ability of the students confronting a concrete case to collect all the relevant data and to suggest the positive procedures applicable to the conditions disclosed" (1). This quotation was the catalyst for the thesis. At the time, Medical Schools and Postgraduate Royal Colleges in the UK were moving away from the traditional examination format. Computer marked multiple choice question papers were replacing essays. Objective Structured Clinical Examinations (OSCEs) were being developed in lieu of long cases, short cases and orals. Those of us involved in the change were facing resistance from clinicians wedded to old methods $(2,3)$. The concerns centred partly (covertly) on the loss of a much valued interaction between examiner and candidate. The overt objection was the failure of new methods to assess the true art of being a doctor; that is the fully integrated process of reaching a diagnosis and formulating a management plan. One had sympathy with these arguments. The new methods do "atomise" clinical skills and there is increasing concern over this trend $(4,5)$. Clinical competence is learnt by travelling a long complex training pathway from novice to expert (6) where experience as well as knowledge build competency (4). So why is such a complicated skill, which requires a long course of training and a complex cognitive diagnostic ability, no longer assessed in the integrated way recommendled by Flexner? Concern that we may have abandoned tradition too hastily formulated the research question overarching the thesis:

"Ilave we becometoo "atomistic" in our approach lo assessing clinical competence? Are we ustified in abandoning the more integrated traditional/ high stakes examinations formats, in particular the long case, too early without either atlempting to improve their validity or measuring their reliability?

There are sound reasons for the move to a less integrated more objective assessment methodology. Chapter two summarises, from an international perspective, the key theoretical principles underpinning the currently available tools for assessing clinicall competence. The paper highlights the key aspect of assessing clinical competency which traditional methods fail to addiress: content specificity. Professionals do mot perform consistently from task to task (7). The content of examinations needs careful planning to ensure students are both comprehensively and fairly assessed. Wide sampling of content is essential (8). This is hardly surprising when one considers the diverse training pathways doctors follow. In the UK alone, although guidelines for undergraduate education have been set and are monitored by the General Medical Council (GMC) (9), there is no published national UK medical school core curriculum. Schools vary in teaching methods and learning contexts. Even within the hospital environment, increasing specialisation and the loss of the generalist medical or surgical firm, results in more diversity of experience. Students attached to a firm with a respiratory interest see very different patients from those 
hospitalised on a renal firm. They may not necessarily experience both types of attachment. Context of learning impacts on clinical competence in a most profound way. Sampling broadly to cover the full range of the curriculum is of paramount importance if fair and reliable examinations are to be guaranteed. Small wonder therefore that the tradition of assessing a doctor's clinical competence only a single long case patient led to its demise.

The second factor has been the move to measure the outcomes of learning rather than the process of reasoning. This change reflects, to a lesser extent, an increasing recognition that the development of clinical expertise involves a complex cognitive process (5). A first year clinical student approaches a clinical problem very differently from a postgraduate trainee. Similarly critical incidents during training impact on subsequent practice. A bad experience, however unusual, may weigh heavily on subsequent judgements and bias future management decisions. Progress along the novice to expert pathway results in an individualistic approach to practice (9). Recognition that the process of reasoning varies in this way, has instigated the move towards outcomes based curricula; learning objectives are defined as competency outcomes and do not reflect the process of reasoning. This new educational understanding sparked the move to base clinical assessment on outcome based competencies.

Political influence has ultimately fuelled the drive to implement this change. In the UK, increased demands for professional accountability to the public (11) have put pressure on both undergraduate and postgraduate programmes to develop more transparent measures of product rather than process. Some argue that learning outcomes should be explicit in this way $(12,13)$. There can be little doubt that, in the UK, pressures from the National Health Service (NHS) and Department of Health $(\mathrm{DOH})$ are driving through "outcome" rather than "process" orientated training programmes.

This has led to a much more behaviourist approach when defining learning outcomes. Clinical competence is commonly categorised into the behaviourist traits of "knowledge", "skills" and "attitudes" (8) and many medical schools use Bloom's taxonomy to employ precise descriptors for the outcomes (14). This in itself has challenged those designing assessments to measure these traits individually. It has encouraged the use of a battery of tests to measure competence rather than a single assessment method.

There has been a tendency to breakdown the integrated nature of clinical competence into these three traits and search for assessment tools for each e.g., an OSCE to measure skills, a Multiple Choice Question paper (MCQ) to measure knowledge. Assessing outcomes has taken the focus off process and promoted the development 
of more objective atomised methods: ln a MCQ, the answer gains the marks not the process of reaching it. In an OSCE, candidates demonstrate competence on itemised skills without discussion of the underlying rationale for the procedure or reasoning to support the conclusion. Chapter wo reviews the international literature on current assessment methods in the light of both content specificity and the importance of sampling broddly. It acknowledges the new focus on assessing product rather than process. No single assessment method is perfect. All are flawed in one way or the other; either in terms of validity or reliability or through issues of feasibility and cost. Thus it seemed opportune to revisit traditional methods in the 12 light of current psychometric practice.

The research carried out in this thesis, took advantage of the change from traditional to new assessments as it occurred in final examinations at a London Medical School. The curriculum outcomes were defined as knowledge, skills and attitudes to meet the GMC recommendations. In 1998 an OSCE was being developed and a long case was still in place. A MCQ was becoming the core test of knowledge but long and short essays were still being used to appraise the candidate's ability to reason through writing. Thus a complex battery of tests was in use. A specific research question was asked of this final examination format.

"How reliable is a composite final year undergraduate examination which uses a range of assessments both traditional and new?

Chapter three outlines the study carried out to address this question. The results highlighted the need to carefully balance the composition and content of these complex high stakes examinations.

The combination of the OSCE and the long case also provided a valuable research opportunity. Long cases were abandoned in the USA as an assessment method many years ago because of issues of content specificity, This decision was based on assumption rather than strong psychometric evidence. Very little was known about the validity or reliability of the llong case (15). Indeed there was no published data on inter-case reliability; no one had compared candidate performance across two non standardised long cases. This formulated the question:

What is the generallisability of the long case? How nany cases would be needed 10 achieve a reliable high stakes test?

A further research question arose. In the traditional long case, candidates are given uninterupted and unobserved time, to interview and examine a patient, selected from the wards or outpatients and untrained for examinations. Candidates then 
present their findings to the examiners as in an unstructured oral examination. Essentially the judgements centre on the presentation of the case.

Can the validity of we long case be improved by observation?

The format had in fact been modified in the examination studied as only the presentation of the history taking (HT) part of the long case was being assessed. The canddate was not expected to examine the patient. The decisilon had been taken to exclude this as physical examination skills were tested in the OSCE, Candidates sat the HT long case within the OSCE.

Two modifications to the examination were requested from the examination board to research the above questions. Firstly it was agreed to include a second $H T$ long case. Unstandardised real patients would be randomly allocated to both thus maintaining the tradition of the long case. This enabled comparison of student pertormance across two cases. A generalisability study of the HT long case was carried out (chapter four) Secondly the HT long case was changed to include observation and marking of the history taking interaction with the patient as well as the presentation of the case to the examiners. The impact of observing and rating the interaction as well as the presentation on the assessment was measured. Comparison of student performance on components of the HT long case with their OSCE marks was also then possible (chapter five).

One question led to another. The findings on the generalisability study of the HT long case raised a further issue. Little is known on the psychometrics of orals. Indeed given that examiners traditionally ask individual unstandardised questions at random without attention to sampling, generalisability studies are difficult to organise. The Royal College of General Practitioners (RCGP) use orals as part of their modular membership examination (MRCGP) to assess deciston making. At the time the oral examination had been restructured using a planning grid to encourage broader sampling and standardisation of delivery. As each examiner continued to develop their own questions, the traditional principles were still in place. This provided an ideal opportunity, as I was at the time convening the MRCGP orals, to further understanding of the reliability of the oral examination format and ask the research question (chapter 6 ):

What is the general isability of the oral examination? How many questions would be needed lo achieve a reliable high stakes test?

Finally observing any assessment in detail is bound to inspire further curiosity. Concerns over the design of the OSCE also arose. In the final London medical 
school examination used for the study fifty percent of the students were from ethnic minorities whereas the majority of examiners were white. The results for the OSCE raised some anxiety. Whereas the top performers were predominantly white female, a high proportion of the students who failed were from ethnic minorities. Were the claims being made of the new assessment methods sound? How objective was the OSCE or was there intrinsic bias within the structure of the stations or the examiner ratings? Of prime concern were the communication stations. Although aiming for objectivity, there was undoubtedly potential within marking schedules for personal judgement to impact on the ratings. In this OSCE examiners completed a communication skill check list and then both role players and examiners independently assigned a global mark for overall performance. There was potential for bias. Would a Chinese role player interacting with a Chinese student judge performance differently from an Asian or White student? Do White examiners have different expectations of Ethnic Minority students compared to White ones? It seemed possible that itemising and standardising communication skills had not necessarily ensured objectivity of ratings. The final research question stimulated by this examination and addressed in chapter seven was:

Despite standardisation and temisation of communication skill stations in an OSCE was there still potential for bias in ratings?

The overall aim was to examine traditional assessment methods in the light of the new. The research was supported by the examination board of the United Medical and Dental school of Guy's and St. Thomas (UMDS) and Professor Cees van der Vleuten and staff of the Department of Eclucation, Maastricht University. Ethical approval was given for the final study (chapter 7) which was supported by a grant from the Kings Fund, London. The findings described in the following chapters illustrate the importance of this collaboration without which none of this research could have been achieved 


\section{References}

1. Flexner A. (1910). Medical education in the United States and Canada. Bethesda, MD: Science and Health Publications.

2. Meadow R. The structured exam has taken over. BM/1998; 317:1329.

3. Fraser R. Letters. Does obserwation add to the validity of the long case? Med Educ $2001 ; 35: 1731-3$

4. Talbot M. Monkey see, monkey do: a critique of the competency model in graduate medical education. Med Educ 2004; 38:587-92

5. Rees CE. The problem with outcomes-based curricula in medical education: insights from educational theory. Med Educ 2004; 38:593-8

6. Boshuizen HPA, Schmidt HG. The development of dinical reasoning expertise. In Clin. ical Reasoning in the Heath Professions. Ed Higgs l Jones M Butterworth-Heinemann 1995: pp 24-32.

7. Swanson DB, Norman GR, Linn RL Performance-based assessment: Lessons learnt from the health professions. Educ Res $1995 ; 24(5): 5-11$

8. Dauphinee $D$, Fabb $W$, Jolly B, Langsley $D$, Wealthall $S$, Procopis $P$. Determining the content of certifying examinations. In The certification and recertification of Doctors:

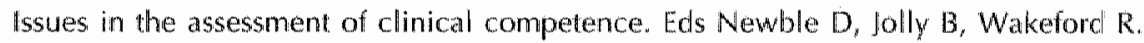
Cambridge University Press 1994; pp92-104

9. The General Medical Council Education Committee Tomorrow's Doctors:

Recommendations on Undergraduate Medical Education. London: General Medical Council; 2003

10. Patel V, Groen Cil. The general and specific nature of medical expertise: a critical look. In Towards a General Theory of Expertise. Properties and Limits. Ed K.A. Ericsson, Smith 1. Cambridge University Press 1991; pp 93-125

11. Cookson IB. The new NHS and undergraduate medical education. Med Educ 2001; 35:195-6

12. Harden RM. Developments in outcome-based education. Med Teacher 2002; $24: 117-20$

13. Bligh J. Prideaux D, Parsell G. PRISMS: new educational strategies for medical educam tion. Med Educ 2001; 35:520 1

14. Bloom BS. Taxonomy of Educational Objectives: the Classification of Educational Coals: Handbook 1. Cognitive Domain. Green, New York: Longmans 1956

15. Vleuten van der CPM. Making the best of the "long case". Lancet. 1996; 347:704-5. 


\section{The assessment of clinical competence}

Val Wass

Senior Lecturer in General Practice,

Guy's King's and St Thomas' School of Medicine, London

\section{Cees Van der Vleuten}

Professor of Education,

Department of Educational Development and Research,

University of Maastricht, Maastricht, Netherlands.

\section{John Shatzer}

Director of Medical Education Services

Johns Hopkins University School of Medicine, Baltimore, USA

\section{Roger Jones}

Wolfson Professor of General Practice

Guy's, King's and St Thomas' School of Medicine, London

Published: Lancet 2001; 357: 945-9. 


\section{Chapter Summary}

This anticle formed part of a series on medical education commissioned by the Lancet and accepted after peer review. The key literature on the assessment of clinical competence available at the time of the study was reviewed from an international perspective. Concepts essential to the understanding of the assessment of clinical competence are outlined and serve as an introduction to the subsequent chapters. The importance of carefully blueprinting the content of examinations against the curricula, seiting appropriate standards, balancing the validity of the tests against their reliability and weighing the formative and summative functions of the assessment are outlined. The paper concludes that current examination formats tend to focus too heavily on knowledge based competencies. Further research into the format and reliability of composite medical examinations is important. 


\section{Introduction}

Assessment drives learning. Many would like to argue that this is not the case and that the curriculum is the key in any clinical course. In reality students invariably feel overloaded by work and respond by studying only for those parts of the course that are assessed. To promote learning, assessment should be educationat and "formative". Students should learm from tests and receive feedback on which to build their knowledge and skills. Pragmatically, it is the most appropriate engine to which to harness the curriculum.

At the same time, with an increasing focus on the performance of doctors and public demand for assurance that doctors are competent to practise, assessment also needs to have at "summative" function. Tests of clinical competence, on which to make an end point decision on whether a doctor is fit to practise or not, are in demand. This raises a challenge for all involved in medical education. It is difficult for a test to have a formative and summative function at the same time. Yet if assessment focuses only on certification and exclusion, the all important influence on the learning process will be lost. There are key measurement issues that must be addressed when designing assessments of clinical competencies (1):

\section{Blueprinting: the assessment of knowledge versus skills and attitudes}

It follows that, if students focus on learning only what is assessed, assessments in medical education must validate the objectives set by the curriculum. Test content must be carefully planned against learning objectives, a process known as "blue printing" (2). For undergraduate curricula, where the definition of core content is now becoming a requirement 3 , this may be easier than for postgracluate collegiate examinations, where curriculum content remains more broadly defined. However, conceptual frameworks against which to plan assessments are essential and can be defined even for generalist collegiate tests (4).

The assessment programme must also match the competencies being learnt and the teaching formats being used. Many medical curricula define objectives in terms of knowledge, skills and attitudes. These can not validly be assessed by a single test format and all tests must ensure the appropriateness of the test being used to the objective being tested. A multiple choice question (MCQ) may be a more valid test of knowledge than of communication skills where an interactive test is required. To assess clinical competence validly, a battery of different tests may be needed. No single one can be valid, given the complexity of clinical competency itself. 


\section{Standard setting: norm versus criterion referencing}

Inferences about examinee performance are critical to any test of competence. When assessment is used for summative purposes, the pass/fail level of a test has also to be defined. Comparison of performance to peers, i.e norm referencing is frequently used in examination procedures where a specified number of candidates are required to pass, for example in some collegiate membership examinations. performance is described relative to the positions of other candidates. This means that variation in difficulty of the test is compensated for. However, variations in ability of student cohorts sitting the test are not taken into account. If the group is above average in ability, those who might have passed in a poorer cohort of students will fail. This is clearly unacceptable for clinical competency licensing tests, which aim to ensure that candidates are safe to practise. A clear standard needs to be defined, below which the doctor would not be considered fit to practise. Such standards are set by criterion referencing, where the minimum standard acceptable is decicled before the test. The reverse problem now faces the assessor. Although differences in candidate ability are accounted for, variation in test difficulty becomes the key issue. Standards should be set for each test, item by item. Various methods have been developed to do this e.g. "Angoff" and "Ebel" (5). These are time consuming but essential. The choice of method will depend on available resources and the consequences of misclassifying passing and failing examinees.

\section{Validity versus reliability}

Just as summative and formative elements of assessment need careful attention when planning clinical competence testing, so do the issues of reliability and validity.

Reliability is the measure of the reproducibility or consistency of a test. It is affected by many sources of potential error such as examiner judgements, cases used, candidate nervousness and test conditions. Two aspects of reliabillty have been well researched: inter-rater and inter-case reliability. Inter-rater reliability measures the consistency of rating of performance among different examiners. The use of multiple examiners across different cases improves the inter-rater reliability. In an oral examination, the average judgement of ten examiners each assessing the candidate on one question produces a more reliable test than one examiner asking ten questions $(6)$

The consistency of performance of the candidate across the cases (inter-case reliability) is perhaps currently the most important issue in clinical competence testing. Doctors do not perform consistently from task to task (7). A good performance on 


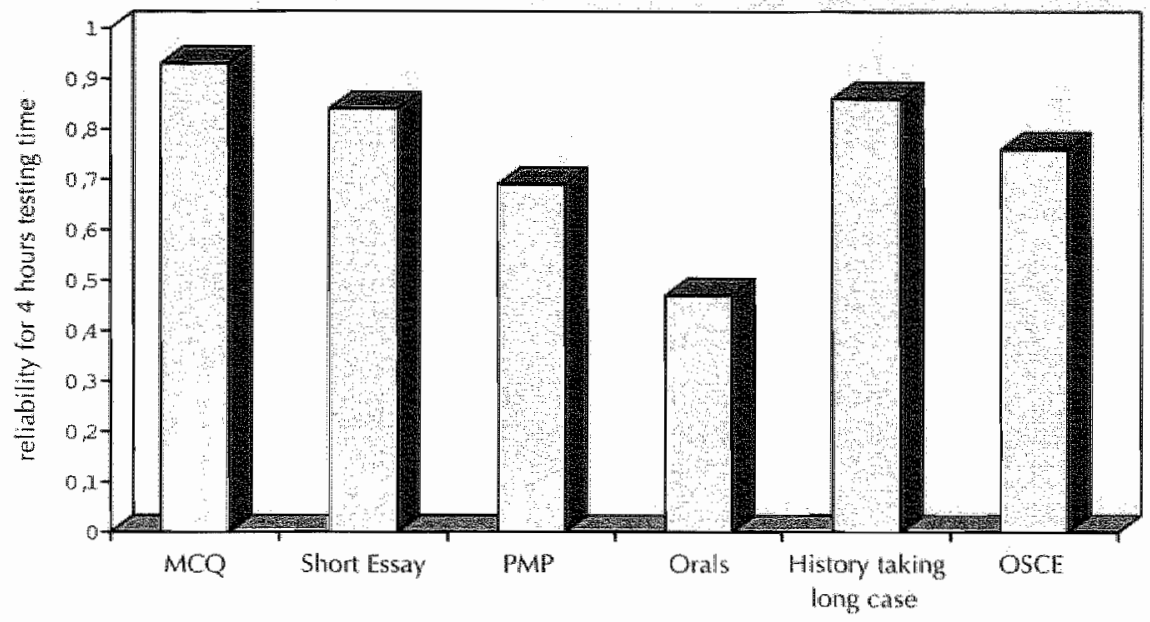

Figure 1: Reported reliability using four hours of testing ime for different test formats (Refs: $\mathrm{MCQ}^{8}$ Short Essay ${ }^{9}$ PMP $^{8}$ Orals $^{6}$ History taking ${ }^{10} \mathrm{OSCE}^{11}$,

one case does not predict a good performance on the next. Broad sampling across cases is essential to assess clinical competence reliably. This observation may not be surprising, given the differences in individual experiences encountered during training and practice, but it challenges the traditional approach to clinical competence testing, where candidate's competencies were assessed on one long case only. Clinical skills tests have moved into the multi-case format with the development of the objective structured clinical examination (OSCE). A large number of stations and sufficient testing time are essential in order to achieve adequate inter-case reliability for the test. It is becoming increasingly clear that whatever the test format, test length is critical to the reliability of any clinical competence test. Figure 1 shows reporfed reliabilities for four hours of testing time using different lest formats.

Validity, on the other hand, focuses on whether a test actually does succeed in testing the competencies it is designed to test. To produce valid assessment methods which measure all facets of clinical competence remains an unresolved challenge. A simple conceptual model which outlines the issues involved when analysing validity is the pyramid of competence (figure 2) introduced by Miller (12).

The pyramid conceptualises the essential facets of clinical competence. The base represents the knowledge components of competence: "knows" (basic facts) followed by "knows how" (applied knowledge). These can be more easily assessed using basic written tests of clinical knowledge such as multiple-choice questions. Clearly this test format cannot assess the next important facet of competency required of a qualifying doctor i.e. the "shows how". This is a behavioural rather 


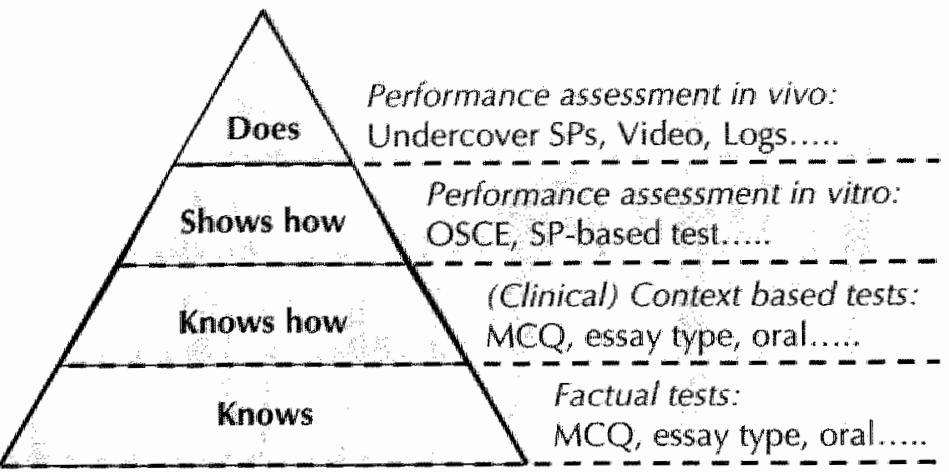

Figure 2: Miller's model of clinical competence

than a cognitive function i.e. it is "hands on" and not "in the head". A senior student about to start work with patients must be able to demonstrate an ability to assess patients and carry out the necessary procedures. However, the ultimate goal for a valid assessment of clinical competence would be to test performance i.e. what the doctor actually does in the working place. Over the last four decades assessment research has focused on developing valid ways of assessing the summit of the pyramid i.e. a doctor's actual performance.

\section{Developments in assessment formats}

\section{The assessment of "knows" and "knows how".}

The assessment of medical undergraduates has tended to focus on the pyramid base: "knows" i.e. the straight factual recall of knowledge and "knows how" i.e. the application of knowledge to problem solving and decision making. This may be more appropriate in the early stages of the medical curriculum but, as skills teaching becomes more vertically integrated, careful planning of assessment formats becomes crucial. Tests of factual recall can take a variety of formats, which are on the whole easier to devise and deliver. Multiple choice formats are universally the most widely used. Although time consuming to set, these tests have high reliability, because a large number of items can easily be tested and marked. This test format remains very popular. A variety of other question formats exist, such as true/false, single best answer, extended matching (13), short and long menus of options (14). Although reliable, criticism of the validity of the MCQ has stimulated much research into alternative options. Many argue that only "trivial" knowledge can be tested. By giving options, candidates are cued to respond and the active generation of knowledge is avoided. 
Table 1: The assessment of clinical competence: Key issues which underpin any test

Key issues

Summative / formative

Be clear on the purpose of the test.

Blue printing

Plan the lest against the learning objectives of the course or competencies essential to the speciality.

Validity

Select appropriate test formats for the competencies to be tested. This invariably results in a composite examination.

Reliability

Sample adequately. Clinical competencies are inconsistent across different tasks. Test length is crucial if high stakes decisions are required. Use as many examiners as possible.

Standard setting

Define end point of assessment. Set the appropriate standard e.g. minimum competence in advance.

Other test formats have been used to assess factual knowledge. Essay and oral examinations have remained popular in the UK, despite their exclusion for more than 20 years from assessments in North America on grounds of unreliability. Essays are notoriously difficult to mark consistently (15) and orals are unreliable due to issues already discussed; lack of standardisation of questions, insufficient judges and lack of sufficient testing time (6). Yet these have remained popular assessment tools in the UK, and other European countries, with many arguing that the ability to recall and synthesise information can best be judged in the face to face encounter. Unfortunately, the reconciliation of validity arguments with reliability issues is almost impossible.

This has led to an increasing focus on testing the "knows how" i.e. the assessment of knowledge as applied to problem solving or clinical reasoning in specific contexts. All the test formats mentioned above can be adlapted to test knowledge across different contexts. Clinical scenarios can be applied to multiple choice formats such as single best answer or extended matching, and to orals. However, it has not proved easy to set questions which test application rather than straight delivery of factual knowledge (16). Rather surprisingly, problem solving appears to be both closely linked to knowledge and also to be content specific i.e. a candidate's problem solving ability is inconsistent across different tasks. As in all areas of clinical competence testing, inter-case reliability becomes an issue (16). This is more easily solved for written formats where a large number of questions can be covered relatively quickly. However the use of orals and essays is hampered by the low generalisability of problem solving skills. Swanson (6) calculated that it would take 12 to 16 case histories in oral examinations to achieve an acceptable level of generalisability $(0.8)$. Similar difficulties apply to orals even when examiners are trained (17). 
The "knows how of ethical situations and attitudinal issues can also be explored through orals and essays. The examination for membership of the Royal College of General Practitioners in the UK uses orals to assess decision making in a structured question setting format. An area of focus is professional and personal development. A recent publication highlights the difficulties of ensuring a fair assessment in this arena, for example if English is not the candidate's first language (18).

In the past, UK medical schools have used short orals for candidates with borderline results on written tests. to make judgements on whether they should pass or not. It is not rational to use an oral, one of the most unreliable assessment tools, to make the most crucial pass/fail decision on a borderline written test. This practice is gradually being abandoned. The focus should be on making the written test as reliable as possible to be confident of the pass/fail decision. However, some schools still use vivas to ratify crucial high stakes decisions resultant on a candidate's written performance.

Difficulties arise in setting "knows how" tests, both in marrying the application of knowledge to the large range of problems required to achieve good inter-case reliability and in distinguishing between responses cued by straight factual knowledge ("knows") from thought processes stimulated by the problem ("knows how"). Formats have been developed such al "key feature" test developed in Canada (19). These require short "uncued" answers to clinical scenarios but limit the assessment to key issues to enable a large number of scenarios to be covered. Similarly, computer simulations can replace the written or verbal scenarios and, hopefully. with the development of multi media, can be used to raise the level of clinical testing (20). In the past the simulations have been complicated. Dynamic and complex situations have been created which require enormous resources rarely avallable at medical school level. A focus on short simulations to produce the required breadth for tests, which stimulate rather than cue responses, remains a challenge foi those developing this test format.

\section{The assessment of "shows how"}

Traditional long and short cases.

Although abandoned for many years in North America, the use of unstandardised real pattents in long and short cases to assess clinical competence remains a feature of both undergraduate and postgraduate UK assessments. Such examinations are increasingly challenged on the grounds of both authenticity and unreliability. Long cases are often unobserved. The assessment relies on the candidate"s presentation, representing an assessment of "knows how" rather than "shows how". Generally. only one long case and three of four short cases are used. The low generalisabillity of clinical skills that are content specific is clearly of concern when using this test format. Yet little published psychometric research on long cases has been 
published. Initial data (figure 1) suggests that test length is again the key to improving reliability in this form of testing and that ten observed history taking long cases rather than the traditional one, may achieve the test rellability required of a high stakes examination (10).

However, attempts have been made to improve the long case format. A more structured presentation of an unobserved long case, which includes some direct observation of the candidate interacting with the patient, the Objective Structured Long Examination Record (OSLER) has been developed (21). Observed long cases are also used in some institutions $(22,23)$. Decreasing the length of time available to

assess a case and allowing more cases to be assessed within a given testing time may also be an option (24). However, this requires balancing the station length that provides the most reliable results with a length that reflects clinical practice. Unless the format of long and short cases is improved by direct observation and the test length is extended to include many more cases, the unreliability of this traditional format does not justify its use. An unreliable test cannot be valid.

\section{The Objective Structured Clinical Examination}

As a potential solution to the problems of adequate sampling and standardisation of cases, the OSCE (25) has gained increasing importance on both sides of the Atlantic. Candidates rotate through a series of stations based on clinical skills applied in a range of contexts. Wide sampling of cases and the structured assessm ment improve reliability but this examination format is expensive and labour intensive. Validity may be lost at the expense of reliability as complex skills, requiring an integrated professional judgement, become fragmented by the relatively short station length (generally 5-10 minutes).

Assessment of communication skills and attitudes can also be attempled in the OSCE. Interestingly these are proving to be case specific and have low generalisability across clinical contexts. Collyer has shown that to reliably assess "empathy" as many as thirty seven different scenarios may be needed (26). However, patient perception questionnaires that include aspects of physician communication are used in many standardised patient assessments and have been found to be quite reliable (27). Who should be the judge: the patient or examiner?

It does not seem to matter $(28,29)$. Scoring against a check list of items is not as objective as originally supposed (30). There is increasing evidence that global ratings, particularly by physicians, are as reliable as check list formats $(31,32)$. However, extensive rater training is required to ensure consistency. Neither global or checklist ratings offer a true "gold standard" of judging performance. While checklists may not capture all aspects of the physician-patient interaction, global ratings may be subject to other rater biases, and the choice of their use may depend 
on the tesources available during the assessment. $A$ third alternative uses informathon collected at "post-encounter" stations, now used in North America and Canada, where students spend five to seven minutes recording their findings from the (simulated) patient encounter. Williams and McLaughlin explored the use of a patient findings questionnaire (PFQ), comparing it to the checklist performance record of the standardised patient $(27)$. Both instruments yielded similar data acquisition scores and pass/fall decisions at both the item and test level. The authors argue that the PFQ minimises some of the shortcomings of checklists and relies solely on the data collection abilities of the examinee to score performance.

\section{Standardised patients}

The use of standardised patients versus real patients remains an area of interest. Simulations are the norm in North America. Extensive training to ensure reproducibility and consistency of scenarios is carried out. Given the high reliabilities required of the North American licensing tests, the high costs of training can be justified but, perhaps, at the cost of validity. Performance on an OSCE may not be the same as performance in real life (33). Clearly this is the focus of testing at the very tip of the pyramid i.e. "performance".

\section{The assessment of "does"}

The real challenge lies in the assessment of a student's actual performance on the wards or in the consulting room i.e. the top of the pyramid. Increasing attention is being placed on this in the postgraduate assessment arena, because revalidation of a clinician's fitness to practise and the identification of poorly performing doctors are areas of public concern. Any attempt at assessment of performance again has to balance the issues of validity and reliability. There is as yet, little research into possible approaches to this in undergraduate medical schools. Some UK schools use in-course assessment and student portfolios to assess student performance in the final year, rather than a summative final examination. Whether such methods are robust enough to cover the issue of content specificity and have the necessary comprehensiveness of the assessments discussed above remains to be seen.

Further research into the format and reliability of composite medical examinations. and the use of portfolio assessment is important. Current examination formats tend to focus too heavily on knowledge based competencies. Assessment at the apex of Miller's pyramid, "the does", is the international challenge of the century for all involved in clinical competence testing. The development of reliable measurements of student performance with predictive validity of subsequent clinical competencies and a simultaneous educational role (34) is a gold standard yet to be achieved. 


\section{References}

1. Neufeld VR, Norman GR. "Assessing Clinical Competence." 1985 Springer Serties on Medical Edwcation, Vol 7 Springer, NY,

2. Dauphinee D. Determining the content of certification examinations. In Newble $D$, Jolly $\mathrm{B}$, Wakeford $\mathrm{R}$. "The certification and recertification of Doctors: Issues in the assessment of clinical competence." 1994; pp 92-104 Cambridge University Press.

3. The General Medical Council Education Committee Tomorrow"s Doctors: Recommendations on Undergraduate Medical Education. London: General Medical Council; 1993

4. Hays $R$ B, Vleuten C P M van der, Fabb W E, Spike N A. Longitudinal reliability of the Royal Australian College of General Practitioners Certification Examination. Med Educ $1995 ; 29: 317-21$.

5. Cusimano MD. Standard setting in Medical Education. Acad Med 1996; 71 (10 Suppl): S112-20

6. Swanson, DB. A measurement framework for performance based tests. In I.R. Hart, \& R.M. Harden. (Eds). Further developments in assessing clinical competence 1987; pp 13-45. Montreal: Can-Heal

7. Swanson DB, Norman GR, Linn RL Performance-based assessment: Lessons learnt from the health professions. Educ Res 1995; 24 (5):5-11

8. Norcini IJ, Swanson DB, Grosso L.J, Shea JA, Webster GD. Reliability, validity and efficiency of multiple choice questions and patient management problem items formats in the assessment of physician competence. Med Educ 1985; 19:238-47.

9. Stallenhoef-Halling BF, Vleuten CPM van der, Jaspers TAM, Fiolet JFBM. The feasibility, acceptability and reliability of open-ended questions in a problem based learning curriculum. In Bender W, Hiemstra RJ Scherpbier AJJA, Zwiestra RP. Eds Teaching and assessing clinical competence. Groningen: Boekwerk Publ 1990; 18:1020-31

10. Wass $V$, Jones $R$, Vleuten CPM van der. Standardised or real patients to test clinical competence? The long case revisited. Med Educ 2001:35:321-5.

11. Newble D 1, Swanson D B. Psychometric characteristics of the objective structured clinical examination. Med Educ 1996; 22:325 34 .

12. Miller $\mathrm{G} E$. The assessment of clinical skills/competence/performance. Acad Med 1990; $65: 563-7$

13. Case $S M$, Swanson DB. Extended Matching Items: a practical alternative to free response questions. Teach Learn Med 1993; 5:107-15.

14. Case SM, Swanson DB. Constructing Written Test Questions for the Basic and Clinical Sciences. National Board of Examiners: Philadelphia, 1996.

15. Frijns PHAM, Vleuten CPM van der, Verwijnen CM, Van Leeuwen YD. (1990) The effect of structure in scoring methods on the reproducibility of tests using open ended questions. In W. Bender, R.J.Hiemstra, A.J.J.A.Scherbier \& R.P. Zwierstra. (Eds) Teaching and assessing clinical competence (pp. 466-471) Boekwerk.

16. Van der Vleuten, CPM. The assessment of professional competence: Developments, research and practical implications. Adv Health Sci Educ 1996; 1:41-67.

17. Wakeford $R$, Southgate $L$, Wass V. Improving oral examinations: selecting training and monitoring examiners for the MRCCP. B M/1995; $311: 931-5$

18. Roberts C, Sarangi S, Southgate L, Wakeford R, Wass V. Oral examinations, equal opportunities and ethnicity: fairness issues in the MRCGP. BM/ 2000; 320:370-4 
19. Page $G$, Bordage $G$. Allen T. Developing key-teature problems and examinations to assess dinical decision-making skills. Acad Med 1995; 70:194-201.

20. Schuwith LWT, van der Vleuten CPM, de Kock CA, Peperkamp AGW, Donkers HHLM. Computeristed case-based testing: a modern method to assess clinical decision making. Medical Teacher 1996; 18, 294-9.

21. Gleeson F. The effect of immedrate feedback on clinical skills using the OSLER. In: Al. Rothman \& R Cohen (Eds.). Proc of the sixth Otawa conference of medical education $1994 ; 412-415$. Toronto: University of Toronto Bookstore Custom Publishing.

22. Newble, DI. The observed long case in clinical assessment. Med Educ 1994; 25:369-73.

23. Price 1, Byme GIA. The direct clinical examination: an alternative method for the assessment of clinical psychiatric skills in undergraduate medical students. Med Educ 1994 28:120-5.

24. Shatzer $\ \mathrm{H}$, Wardrop IL, Williams RC, Hatch, T.F. The Generalizability of Performance of Different Station Length Standardised Patient Cases. Teach Leam Med 1994; 6.54-8

25. Harden RM, Gleeson, FA. ASME Medical Educational Booklet no. 8 Assessment of medical competence using an objective structured dinical examination (OSCE). I Med Educ 1979; $13: 41-54$.

26. Colliver JA, Willis MS, Robbss RS, Cohen DS, Swartz MH. Assessment of empathy in a standardized patient examination. Teach Leam Med 1998; 10:8-11.

27. Williams RG, McLaughlin MA, et al. The patient findings questionnaire: one solution to an important standardized patient examination problem. Acad Med 1999; 74:1118-24.

28. Vleuten CPM van der. Swanson DB. Assessment of clinical skills with standardised patients: State of the Art. Teach Learm Med 1990; 2:58-76.

29. Colliver JA, Verhulst SI, Williams RG, Norcini J], Reliability of performance on standardised patient cases: A comparison of consistency measures based on generalizability theory. Teach Learn Med 1989; 1:31-7

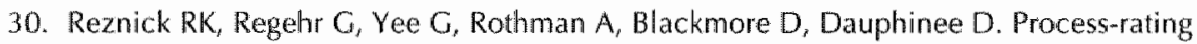
forms versus task-specific checklists in an OSCE for medical licensure. Acad Med 1998; $73: 597-599$.

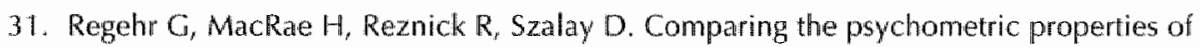
checklists and global rating scales for assessing performance on an OSCE-format examination. Acad Med 1998; 73191993\%7.

32. Swartz MH, Colliver IA, Bardes $\mathrm{Cl}$, Charon $\mathrm{R}$, Fried ED, Moroff $\mathrm{S}$. Global Ratings of Videotaped performance versus global ratings of actions recorded on checklists: a crite. fion for performance assessment with standardized patients. Acad Med 1999; $74: 1028-32$

33. Ram P, Cirol R, Rethans ل), Schouten B, van der Vleuten CPM, Kester A. Assessment of general practitioners by video obserwation of communication and medical performance in daily practice: issues of validity, reliability and feasibility. Med Educ 1999; 33:447-54.

34. Vleuten $C$ van der. Validity of final examinations in undergraduate medical training. BMJ 2000; 321:1217-9. 


\section{Composite undergraduate clinical examinations: how should the components be combined to maximise reliability?}

\section{Dr Val Wass}

Senior Lecturer in General Practice

Department of General Practice and Primary Care,

Guy's, King"s and St Thomas" School of Medicine,

\section{Dr David McGibbon}

Consultant Dermatologist

Guy's, King's and St Thomas' School of Medicine, London, UK.

\section{Professor Cees Van der Vleuten}

Professor of Education,

Department of Educational Development and Research, University of Maastricht, Maastricht, Netherlands.

Published: Medical Education 2001, 35: 326-30.

\section{Acknowledgments}

Dr Charles Twort, Professor Gwyn Williams and Professor Roger Jones kindly supported this study. Dr Mark Kinirions and Professor Amanda Ramirez organised the short answer and essay papers. Mr Ron Hoogenboom carried out the statistical analysis. 


\begin{abstract}
Background: Chinical examinations increasingly consist of composite tests to assess all aspects of the curriculum reconmended by the General Medical Councill 1 .

Setting: A final undergraduate medical school exammation for 214 students.

Am: To estimate the overall reliability of a composite examination, the correlations between the tests, and the effect of differences in test length, number of items and woighing of the results on the reliability.

Method: The examination consisted of four written and wo clinical tests: multiple choice test (MCQ), extended matching items (EMQ), short answer questions (SAQ). essays, an Objective Structured Clinical Examination (OSCE) and history taking long cases. Multivariate generalisability theory was used to estimate the composite reliability of the examination and the effects of item weighting and test length.
\end{abstract}

Results: The composite reliability of the examination was 0.77 , if all tests contributed equally. Correlations between examination components varied, suggesting that different theoretically interpretable parameters of competence were being tested. Weighting tests according to items per test or total test time gave improwed reliabilities of 0.93 of 0.81 respectively. Double weighting of the clinical component marginally affected the reliability $(0.76)$.

Conclusion: This composite final examination achieved an overall reliability sufficient for high stakes decisions on student clinical competence. However, examination structure must be carefully planned and results combined with caution. Weighting according to number of items or lest length significantly affected reliability. The components testing different aspects of knowledge and clinical skils must be carefully balanced; boh to ensure content validity and parity between irems and lest length. 


\section{Introduction}

In response to recommendations from the General Medical Council (1), most United Kingdom medical schools are broadening their educational objectives. More emphasis is being placed on skills training, communication and attitudinal development. This raises important issues in planning assessment procedures. The valid assessment of students" knowledge, skills and attitudes, the core elements of most curricula, requires different forms of test (2). A multiple choice question paper (MCQ) is a good test of student knowledge whereas Objective Structured Clinical Examinations (OSCEs) (3) are increasingly used to examine practical skills. An increasing range of formats is now available to test applied knowledge and problem solving (2), although the assessment of student attitude remains a challenge.

Therefore, many medical schools are developing a battery of tests to parallel these curriculum changes. It is essential for the assessment to be valid; the examination must truly test the learning it sets out to test. However reliability, i.e. the consistency of candidate performance on each test, is equally crucial. Other factors are also important. The feasibility of running and resourcing the examination cannot be ignored. Thus tensions exist when setting these examinations between selection of the test format and the practicalities of delivering it; i.e. a three hour MCQ test requires considerable less resourcing than a three hour OSCE.

A key problem is achieving an acceptable balance between reliability and validity. If the examination is an important end of year or course assessment, i.e. a high stakes one for the student, a reliability of greater than 0.8 is essential to ensure a fair pass/fail decision. Herein lies the problem. The reliabillity of different examination formats varies. A three hour MCQ test includes a high number of items and reliability should be high (above 0.8). For a three hour OSCE, this level of reliability is difficult to achieve (4) and essay papers, unless carefully scored, are unreliable (5). Combining the results from the different tests, rather than assessing them indiviclually, may perhaps achieve a better reliability but this can be difficult to do because the format of the individual tests may be very different. There is little information on composite undergraduate examinations and how to construct them to minimise cost and maximise validity and reliability (6).

When using these high stakes composite tests, how should the overall composite reliability be estimated? Given the limited amount of overall time and the variety of available formats, how should the papers be constructed and combined to achieve maximum reliability? Questions arise relating to the optimum number of items to include in written papers or the appropriate length for clinical tests. Answers will depend on the contribution of these components to the overall reliability. When using a battery of tests, what weight should be given to the different components? 
For example, it may be felt that the clinical skills component should have more weight than a basic knowledge test. What effect does weighing components equally or differentially have on the composite reliability? The aim of this study is to address these questions.

The final qualifying examination for medical students on the Guy's and St Thomas' campus of a London medical school, recently merged with Kings College, is a composite one aiming for validity in as many facets of the undergraduate curriculum as possible. We have analysed the composite relliability from the June 1998 examination using multivariate generalisability theory and investigated the effect of different weightings of the results on the overall reliability of this high stakes examination.

\section{Method}

The study was carried out in the June 1998 Final MBBS examination for undergraduates completing clinical training. Since 1996, the Guy's and St Thomas' campus had taken over responsibility from the University of London for its own final examination. The examination aimed to ensure students" clinical competence before they started pre-registration house officer (PRHO) appointments.

\section{Examination structure}

The school designed a specific composite test format to assess knowledge, skills and attitudes as given in the core curriculum. This consisted of:

\section{Four different written test formats:}

A multiple choice paper (MCQ) (180 minutes) consisting of:

1. True/ False Questions: Ninety question stems from a pre-tested university bank (160 minutes), each with five associated true/ false items, designed to test basic factual knowledge in medicine, surgery, general practice, psychiatry and public health. Each correct answer scored one. A mark was subtracted for an incorrect response.

2. Extended matching questions (EMQ): Six additional extended matching questions (25 single items) were used to assess problem solving skills (7):

Candidates were allocated 20 minutes for the extended matching questions.

3. A shot answer question paper (SAQ) (three hours) of ten questions designed to assess problem solving and data interpretation skills. Two questions used public 
health data and eight used clinical scenarios. Each question was first marked independently out of 20 by two examiners, who agreed a final score.

4. An essay paper (two and half hours) of three questions designed to assess both the ability to present written debate and communicate with professional colleagues. One compulsory question on writing a discharge letter and two essay choices from (1) ten broad philosophical topics and (2) ten more knowledge based titles. Each essay was marked independently by two examiners using a clased fixed percentage range $(65 / 60 / / 55 / 50 / 48 / 45 / 40 / 35)$ where $65 \%$ was excellent, $48 \%$ borderline and $45 \%$ or below a fail.

\section{Two clinical tests}

1. An OSCE (two hours and twenty minutes) of twenty stations of seven minutes each. The examination was blueprinted from the clinical core curriculum with 8 clinical examination, 6 communication, 4 practical skills and 2 radiology stations. Each station was marked against a checklist by one examiner.

(b) Two history taking long cases: (21 minutes each) These assessed the candidate's interaction with real unstandardised patients. Candidates had 14 minutes observed by the examiner to interview the patient. Physical examination was not carried out. They then presented the case in seven minutes to the same examiner(s). A checklist was used to measure the data gathering process and global scores for the presentation and candidate's attitude to the patient. Each candidate had two cases with different examiners.

\section{Statistics:}

The reliability of the composite examination was estimated using multivariate generalisability theory (8). This allows estimation of multiple true and error score variances, each true and error score associated with each subtest. The approach pools variance components and covariance components across subtests to a single composite estimate. All scores on items within subtests were expressed on the same percentage scale. Variance components per subtest were then estimated using a one facet generalisability design with items nested within persons (students). Covariance components were estimated for each subtest combination from the product of the respective variance components weighted by their intercorrelation.

Thus a matrix of person variance components and error variance components was obtained and used to estimate a composite reliability coefficient. The reliability coefficient can be interpreted as appropriate for absolute score interpretation. It is a more demanding interpretation of examination scores, yielding lower reliability estimates than a more common relative score interpretation (i.e. norm referencing). The approach allows optional subtest weighting and assessment of the contribution 
of each subtest to composite reliability. The latter was used to find directions for improving the overall reliability by changing the weights and number of items within each of the subtests. The approach also allows estimation of "true" or disattenuated correlations between subtests. More detailed technical information can be found in Brennan (8) and Hays (9).

\section{Results}

34 Two hundred and fourteen candidates took the examination. The total test time was 11 hours 32 minutes: 8 hours written and $31 / 2$ hours clinical. Table 1 gives details of the number of items, length, average percentage score, standard deviation (SD) and minimum and maximum scores for each test.

Table 2 gives the disattenuated correlations; i.e. the true correlations after factors contributing to the variance between the tests have been corrected for, between the

Table 1: Descriptives of the individual examination components.

\begin{tabular}{lcclcll}
\hline $\begin{array}{l}\text { Examination } \\
\text { component }\end{array}$ & $\begin{array}{l}\text { Number } \\
\text { items }\end{array}$ & $\begin{array}{l}\text { Testing time } \\
\text { (mins) }\end{array}$ & $\begin{array}{l}\text { Awerage } \\
\text { Score } \\
\%\end{array}$ & SD & $\begin{array}{l}\text { Minimum } \\
\text { Score } \\
\%\end{array}$ & $\begin{array}{l}\text { Maximum } \\
\%\end{array}$ \\
\hline True/false items & 450 & 160 & 66.7 & 7.9 & 44.4 & 85.3 \\
EMQ & 25 & 20 & 68.7 & 9.7 & 36.0 & 96.0 \\
SAQ & 10 & 180 & 64.9 & 5.4 & 53.5 & 79.4 \\
OSCE & 20 & 140 & 69.9 & 5.0 & 55.6 & 82.2 \\
Long cases & 2 & 42 & 67.6 & 10.2 & 39.0 & 92.9 \\
Escay & 3 & 150 & 58.7 & 8.3 & 28.6 & 85.7 \\
Total & 510 & 692 & 66.1 & 7.8 & 42.9 & 86.9 \\
\hline
\end{tabular}

$N=214$

Table 2: Disattenuated correlations between the individual examination components:

\begin{tabular}{lccccc}
\hline & EMQ & SAQ & Essay & OSCE & Long case \\
\hline Truetalse itens & 0.43 & 0.46 & 0.33 & 0.21 & 0.01 \\
EMQ & & 0.60 & -0.08 & 0.83 & 0.48 \\
SAQ & & 0.49 & 0.76 & 0.54 \\
Essay & & & 0.30 & 0.51 \\
OSCE & & & & 0.59 \\
\hline
\end{tabular}


Table 3: Reliability scores for different weightings of examination components:

\begin{tabular}{lc}
\hline Applied score weighting & $\begin{array}{c}\text { Ceneralisability coefficien for } \\
\text { combined components }\end{array}$ \\
\hline Components weighted equally & 0.77 \\
Double weighting tor OSCE \& long cases & 0.76 \\
Weighted according to number items & 0.93 \\
Weighted according to testing time & 0.83 \\
\hline
\end{tabular}

individual examination components. Correlation coefficients for the MCQ factual knowledge test with the clinical components were 0.28 with the OSCE and 0.04 with the long cases. Correlation coefficients for the extended matching questions with the short answer questions and OSCE were much higher; at 0.72 and 0.77 respectively. Correlations for the short answer written paper showed the most consistent relationship with the other papers: OSCE 0.78 , long cases $0.54, \mathrm{MCQ}$ 0.56 , Essay 0.54.

The composite reliability scores estimated for the different weightings of the examination components are given in Table 3 .

If each examination format has equal contribution to the reliability, regardless of the number of items or test length in time, the overall reliability was 0.77 . If reliability is estimated by taking into account the number of items in each test, the reliability increased to 0.93 . However this capitalises on the very large number of items in the MCQ. If test length is taken into account instead, i.e. the long cases and extended matching questions contribute less, a reliability of 0.84 is achieved. In this examination, the contribution of the clinical test was doubled. Weighting the composite test in this way reduced the reliability s/ightly to 0.76 .

\section{Discussion}

This final examination aimed for high content validity in assessing the skills required of a final year medical student about to qualify as a pre-registration house officer. As a result, estimation of its overall reliability was difficult because of the composite nature of the tests used. The problems relate to the large choice of essay questions, the random allocation of the long cases, the very large number of items in the MCQ compared to the other papers and the differences in test length. Application of multiwariate generalisability theory enabled us to take these variances into account, estimate the overall reliability and achieve a more meaningful analysis of the impact of each test on the examination overall. We have shown that the composite relliability of the examination was 0.77 when each component was given 
equal weight and differences in test structure accounted for. For a high stakes examination this should be taken as the minimum. A higher value would be desirable.

We have also shown the impact of the different test structures on the composite reliability. When candidate scores were weighted according to the number of test items, the contribution of the MCQ component dominated and the reliability increased to 0.93. This reliability is more acceptable for a high stakes test but the examination also has an important accountability function i.e. it was designed to ensure students were clinically competent to "pass out" of medical school. It could be argued that the content validity of the overall test should be adjusted so that, despite the smaller number of items, clinical tests were equally important. This is further supported by the analysis of this examination as the MCQ factual knowledge test correlated so poorly with the other components. In the final examination the adjustment was made by doubling the weight of the clinical test scores. We have shown that this resulted in a slight fall in the overall reliability which means that care must be taken to balance the content of these examinations. The number of MCQ items used could have been reduced by a half without significantly affecting the composite reliability of the examination.

Alternatively, by adjusting the calculations so that each test had the same length, a modest increase in reliability to 0.83 was obtained. Thus we have demonstrated that by carefully constructing composite examinations, adjusting test length, avoiding imbalance of test items and giving a large choice of questions, the reliability could be improved at the same time maintaining content validity. Hays et al have reported a similar experience when analysis of the Royal Australian College of General Practitioners. Certification Examination was carried out (10).

Was the choice of a variety of tests justified? By adjusting for the variances in the tests, the disattenuated correlations between the components give some idea of whelher the components are testing similar or different skills. The short answer questions were aimed at testing the candidate's problem solving skills when faced with common clinical management problems, and the correlations of this test (around $0.5-0.7$ ) with both the knowledge based and clinical tests, suggest that the skill being tested was different but interrelated. The correlation seen between the basic knowledge test (the MCQ) and the clinical tests is surprisingly low. The MCQ used questions developed over the years testing straight factual, textbook knowledge on diseases. An explanation could be that this knowledge has little relation to more clinical based knowledge the candidate required for performance in the OSCE and long cases and that the SAQ was a more appropriate test of the application of knowledge. The MCQ content may need review with the inclusion of more extended matching questions as these showed a stronger correlation with the SAQ and OSCE tests. These may be more appropriate in these final stages of the curriculum. 
Some members of the examination board, who felt that written debate was not a skill essential to this test of clinical competence, had questioned the inclusion of an essay paper. If the composite relability of the examination is calculated excluding the essay paper and giving equal weight to the others, the overall reliability does not improve but falls to 0.75 . Some clinicians were insistent that good writing skills are essential to future professional practice. We found no evidence to suggest that the inclusion of the essay paper detracted from the overall quality of the examination.

Thus using a variety of tests to improve the content validity of this final examination and test the range of skills required of a preregistration houseofficer resulted in an examination of reasonable reliability. This could however be improved by more careful balancing of the number of test items and length of each test. Given the complexity of the skills being tested and as the emphasis on the development of professional attitudes, communication skills and a patient centred approach to medicine gain momentum in the UK medical curriculum (1), further research into the best format for testing clinical competence at the end of the undergraduate curriculum is urgently needed. 


\section{References}

1. The General Medical Council Education Committee Tomorrow's Doctors: Recommendations on Undergraduate Medical Education. London: General Medical Council; 1993.

2. Van der Vleuten CPM. The assessment of professional competence: Developments, research and practical implications. Adv Health Sci Educ 1996; 1:41-67.

3. Harden RM, Gleeson FA. ASME Medical Educational Booklet no. 8 Assessment of medical competence using an abjective structured clinical examination (OSCE). / Med Educ 1979; 13:41-54.

4. Newble DI, Swanson DB. Psychometric characteristics of the objective structured clinical examination: Med Educ 1996; 22:325-34.

5. Frijns PHAM, Van der Vleuten CPM, Verwijnen GM, Van Leeuwen YD. (1990) The effect of structure in scoring methods on the reproducibility of tests using open ended questions. In W. Bender, R.J. Hiemstra, A.J.J.A. Scherpbier \& R.P. Zwierstra. (Eds) Teaching and assessing clinical competence. (pp. 466-71) Boekwerk.

6. Van der Vleuten CPM. The validity of final examinations. BMI 2000; 321:1217-9.

7. Case SM, Swanson DB. Extended Matching Items: a practical alternative to free response questions. Teach Learn Med 1993; 5:107-15.

8. Brennan RL. (1983) Elements of Generalisability Theory. American College Testing Program, pp133-35, lowa.

9. Hays RB, Fabb WE, van der Vleuten CPM. Reliability of the Fellowship Examination of the Royal Australian College of General Practitioners. Teach Learn Med 1995; 7:43-50

10. Hays RB, van der Vleuten CPM, Fabb WE, Spike NA. Longitudinal reliability of the Royal Australian College of General Practitioners Certification Examination. Med Educ 1995; $29: 317-21$ 


\section{Standardised or real patients to test clinical competence? the long case revisited.}

Dr Val Wass

Senior Lecturer in General Practice

\section{Professor Roger Jones}

Wollfson Professor of General Practice

Department of General Practice and Primary Care,

Guy's, King's and St Thomas' School of Medicine, London, UK.

\section{Professor Cees Van der Vleuten}

Professor of Education,

Department of Educational Development and Research,

University of Maastricht, Maastricht, Netherlands.

Published in Medical Education 2001, 35: 321-5

\section{Acknowledgements}

Professor Gwyn Williams, Dr Charles Twort and the UMDS Finals Examination Board for permission for the study; Mr Ron Hoogenboom for help with the statistical analysis and Professor Brian Jolly for his critical review of the paper. 


\begin{abstract}
Backgrownd: In undergraduate clinical examinations, the use of real patients as long cases is being replaced by Objective Structured Clinical Examinations IOSCES, which use smullated scenarios, although we lack published psychometric data on long cases to support the move from neal to simulated patients.
\end{abstract}

Aim: To assess candidate performance across two history taking long cases to estimate the number of cases required for a reliable assessment. Results are compared wh psychometic data from an OSCE.

Setting: A final year qualifying undergraduate clinical examination.

Method: Two observed history taking long cases were included, alongside an OSCE. Candidates interviewed wo unstandardised real patients. The history taking part (14 minutes) was observed, uninterupted, by examiner(s) who assessed data gathering, interviewing, and diagnostic and management skills. The presentation 7 minutes) was unstructured; examiner(s) intervened as appropriate. Marks were expressed as a percentage of the total possible score and analysed using generalisability theory to estinate inter-case reliability.

Results: Two examiner pairs independently rated both long cases on $79(36.7 \%$ of the 214 candidates. Projections based on generalisability theory showed that 10 Iwenty-minute cases would give reliabilities of 0.84 for single marked and 0.88 for double marked candidates, compared with a projected reliability of 0.73 for the same 214 candidates taking the OSCE.

Conclusion: thistory haing long cases are observed, thee and half hours of resting. time using 10 unstandardised patients would produce a reliable test. Long cases therefore are, in tems of reliability, noworse and no better than OSCEs in assessing clinical competence. 


\section{Introduction}

The long case has been abandoned as a test of clinical competence in North America and Canada but is still used in some high stakes assessments, including. medicall finals, in the UK and Australia (1). As highlighted several years ago (2), there are few psychometric data on the long case to resolve arguments about its validity and reliability as a test $(3,4)$.

Advocates of the long case argue that it has high validity. In the traditional format, candidates are given ample, uninterrupted and unobserved time to interview and examine a real patient untrained for examinations. Candidates present their findings to the examiner(s) as in an unstructured oral. Although the long case examination purports to test the integrated interaction between doctor (student) and patient, it is being gradually replaced in undergraduate assessments by more structured examinations, i.e. Objective Structured Clinical Examinations (OSCEs) (5). These use short standardised stations focused on specific skills and substituting real patients with standardised simulations. However, some clinicians continue to insist that the integrated assessment of the whole, real patient, provided by the long case, is more valid. (6).

The move towards the OSCE is promoted by concerns over the reliability of the long case. Clinical competence is case or content specific i.e. candidates do not perform consistently across clinical tasks $(7,8)$. Reliability is particularly hampered when a small sample of both content or cases (inter-case reliability) and examiners (inter-rater reliability) is used. In the past, studies of examination reliability have usually focused on inter-rater reliability only. However, in recent years, research has shown that examiner variability is but one source of error and perhaps not even the most threatening one (9).

In the OSCE, rater variance hardly plays a role. When candidates are judged by different examiners across a large number of stations, examiner variability "averages" out across the stations. The OSCE requires a large number of stations because of the large inter-case variance of candidate performance. It has been shown that at least three to four hours of testing time, regardless of station length, are required to do so (10). In the long case candidates are traditionally limited to one unobserved long case because of the time constraints of the examination. There are no published data on the performance of candidates aver multiple unstandardised long cases (2), on which to investigate the inter-case effect and generalisability of this form of testing.

The final qualifying examination for medical students of the now merged medical school of Guy's, Kings and St Thomas' in London, includes a history taking long 
case of 21 minutes. This uses real, untramed patients in the traditional way to thest diagnosis and management and includes unstructured presentation of the case to the examiner. To answer some of the above psychometric issues, it was agreed in the examination in June 1998, to include two long cases focused on history taking. The aim was to compare candicate performance across the wo randomly chosen and unstandardised cases and estimate, using generalisabity theory, the number of patient interviews required to produce a reliable examination based on unstandardised long cases only. Direct comparisons could be made with an OSCE carried out at the same time by the same students.

\section{Method}

The study was carried out in June 1998 over three days during the final qualifying examination for fifth year medical students. The clinical component of the examination consisted of a twenty station OSCE examination and one history taking long case retained to meet validity arguments made by the clinicians. For the purpose of the study a second long case of equivalent length was introduced.

On each long case candidates were given 14 minutes to interview the patient, elicit the clinical history and formulate ideas on diagnosis and management. One or two examiners, according to availability, observed the interview. Physical examination of the patient was not carried out. The interview was followed by a seven-minute unstructured presentation of the case to the same examiner(s).

Patients were not standardised. General medical and surgical patients were invited to attend from outpatients and the wards. They were assigned to the long case stations at random; the only specification being that the candidate should not see the same patient twice. The patients had no prior training, although some had previous experience of examinations.

The candidates had different examiners for each long case. All examiners were senior clinicians; the majority had previous experience of examining long cases. There was no selection or specific training procedures for this examination. The aim was for a proportion of the long cases to be independently marked by two examimers. Examiners were given a brief clinical summary of the patient and could supply details of physical findings where relevant. There were no specific instructions for conducting the seven minute presentation.

The fourteen minute observed interview was rated against a previously used check list which itemised key features of history taking: patient details, present illness, past medical history, system review and social history. Ratings for interviewing skills, as 
well as data gathering skills, were included. For the presentation, the examiner(s) used six global ratings on a Likert scale 1 (very poor) to 5 (very good) for attitudinal approach to patient, evaluation of the history, differential diagnosis, current problems, management issues and presentation skills. Candidate scores for each case were expressed as percentages of the maximum score of $77(100 \%)$.

The candidates also took twenty, seven minute OSCE stations, which examined clinical skills ( 8 stations), practical procedures ( 4 stations), psychiatry ( 2 stations), communication skills ( 4 stations) and radiology (2 stations). Single examiners marked these against checklists.

\section{Statistics}

Long case scores were expressed as a percentage of the total possible. Two sets of data were constructed. Data set I comprised data on those candidates for whom double examiner markings were available for both long cases. Data set II consisted of data on all candidates with a score from a single examiner.

For the double marked data set (1) a two facet generalisability study (11) was carried out with examiners and cases as facets (cases nested within candidates and examiners nested within cases and candidates; all random model). Subsequently generalisability coefficients were estimated as projections of different numbers of cases and examiners. This data set was more informative as the effect of changing the number of examiners and cases could be investigated. However, as it was based on a smaller sample of candidates, the reliability estimate may have been less accurate. A one-facet generalisability studly was therefore also carried out on the larger data set II, for both the long cases and the OSCE, with cases nested within candidates all random model. Generalisability coefficients were estimated as a projection of different number of cases. The all inclusive data set II was used to validate estimations of comparable variance components and generalisability coefficients in the smaller data set I. All generalisability coefficients include the effect of both examiner and inter case variability in the overall estimation of reliability but these effects could not be varied independently.

\section{Results}

Two hundred and fourteen candidates took the examination, completing 428 history taking long cases. Overall performance on the two long cases was consistent: Mean percentage score \pm standard deviation was $67.3 \% \pm 12.2 \%$ for case 1 and $67.9 \% \pm 12.7 \%$ for case 2 . One hundred and forty one $(64.7 \%)$ candidates were double marked on the first long case and $119(55.4 \%)$ on the second long 
Table 1: Ceneralisability coefficients calculated for up to 200 minutes of testing time for double and single marked candidates compared to equivalent OSCE testing time.

\begin{tabular}{|c|c|c|c|c|c|}
\hline \multirow{4}{*}{$\begin{array}{l}\text { Tirne } \\
\text { (minutes }\end{array}$} & \multirow{4}{*}{$\begin{array}{l}\text { Number } \\
\text { long cases. } \\
\text { (OSCE } \\
\text { stations) }\end{array}$} & \multicolumn{4}{|c|}{ Number of candidates } \\
\hline & & \multirow{2}{*}{\multicolumn{2}{|c|}{$\begin{array}{l}79 \\
\text { Data set } 1\end{array}$}} & \multirow{2}{*}{\multicolumn{2}{|c|}{$\begin{array}{l}214 \\
\text { Data set II }\end{array}$}} \\
\hline & & & & & \\
\hline & & $\begin{array}{l}\text { Long case } \\
\text { One diferent } \\
\text { examiner } \\
\text { per case }\end{array}$ & $\begin{array}{l}\text { Long case } \\
\text { Two different } \\
\text { examiners } \\
\text { per case }\end{array}$ & $\begin{array}{l}\text { Long case } \\
\text { One different } \\
\text { examiner } \\
\text { per case }\end{array}$ & $\begin{array}{l}\text { OSCE } \\
\text { One different } \\
\text { examiner } \\
\text { per station }\end{array}$ \\
\hline \pm 20 & $1(3)$ & 0.35 & 0.41 & 0.33 & $0.2 \Downarrow$ \\
\hline $\pm 40^{*}$ & $2(6)$ & 0.52 & 0.58 & 0.50 & 0.34 \\
\hline \pm 60 & $3(9)$ & 0.62 & 0.67 & 0.60 & 0.43 \\
\hline$\$ 100$ & $5(15)$ & 0.73 & 0.77 & 0.71 & 0.56 \\
\hline \pm 120 & $6(18)$ & 0.77 & 0.80 & 0.75 & 0.61 \\
\hline \pm 140 & $7(21)$ & 0.79 & 0.82 & 0.78 & 0.64 \\
\hline \pm 160 & $8(24)$ & 0.81 & 0.84 & 0.80 & 0.67 \\
\hline \pm 180 & $9(27)$ & 0.83 & 0.86 & 0.82 & 0.70 \\
\hline \pm 200 & $10(30)$ & 0.84 & 0.87 & 0.83 & 0.72 \\
\hline
\end{tabular}

* Actual test length

case. Seventy nine candidates $(36.7 \%)$ were rated by two examiners on both long cases. All 214 candidates completed the twenty OSCE stations: mean total score $69.7 \% \pm 5.5 \%$

Inter long case correlation:

Table 1 gives, for all candiclates, projected generalisability coefficients for the number of cases and total testing for the 214 single marked and the 79 double marked candidates on the long case. Even with one examiner marking each case, $8-10$ cases are needed to achieve a reliability of greater than 0.8 . The inprovement in reliability using two examiners per case is limited: for 10 cases two examiners would improve the reliability from 0.85 to 0.88 . It should be noted that for each case a different examiner is assumed. Hence with multiple cases, multiple different examiners are used.

Comparison with the OSCE:

Table 1 also gives reliability projections for the OSCE. The reliability for 30 stations was 0.73 compared 0.85 for ten long cases. 


\section{Discussion}

There is no previously published comparison of candidate performance across two history taking long cases using unstandardised patients. We have shown that 8 to 10 twenty minute cases are necessary to assess history taking, diagnosis and management and achieve acceptable reliabilities, using real unstandardised patients. However, this form of testing would give reliability more or less comparable to that achieved for these candidates on the OSCE examination taken concurrently, if extended to equivalent testing time. Our OSCE reliabilities are comparable to reports in the literature (10). Thus, the reliability of the long case - which is much more unstandardised in its testing conditions (patients, examiners, instruction to students, etc) - yields more or less the same reliability as instruments with more standardised test taking conditions such as the OSCE. Both types of instruments yield good or bad reliabilities depending on the sample size they use, but they are comparable in terms of reliability as a function of testing time.

We have also shown that using two rather than one examiners per case produces little improvement to the inter-case reliability. However, as a different examiner examined each case, in a three and a half hour long case examination, a candidate would meet ten examiners. This is consistent with calculations made by Swanson (9) using data from case-based orals. He demonstrated that using a different examiner for each question, rather than two examiners for as series of questions, improved reliability. Moreover, our data suggest that ten long case examiners could assess clinical competence as reliably as 30 examiners on a thirty station OSCE of equivalent testing time. This would represent a significant saving in resources.

In fact, the estimated length of testing time for the history taking long cases is less than might have been predicted. Swanson (9) calculated that it would take 12 to 16 case histories in oral examinations to achieve an acceptable level of generalisability (0.8). Stillman (12) using standardised patients, who were both subjects and the examiners for fouth year medical students, showed that 13 and 17 cases were needed to achieve reliability scores of 0.68 and 0.88 respectively.

There are possible reasons for this. In our study, the long case format differed from traditional format in two respects. Firstly the assessment of the case, excluded the physical examination. This was partly for time reasons and partly because these skills were being tested in the OSCE stations. However the other components of a long case were essentially identical. The candidates were assessing unstandardised patients, selected at random. The element of chance, an intrinsic criticism of this form of testing, remained. They also had to reach, faced with different complexities of the case, diagnostic and management decisions and discuss these on a professional basis. 
However, in the format used, the long case may have assessed a smaller domain of competence related to data gathering and interpretation than that achieved by the OSCE. It is possible that the loss of standardisation in the history taking long case was compensated for by the fact it assessed a more homogeneous domain of clinical competence. On the other hand, Olson has shown using the traditional format that, even for borderline students, performance across two long cases appears to predict performance across disciplines (13). Therefore, provided sufficient testing time is given, the integrated testing of the long case may assess clinical performance just as well as the OSCE does.

Secondly, the interaction between the candidate and patient was observed. Traditionally the candidate only sees the examiner for the presentation. Newble (14) has suggested that the observed long case is an improvement on an oral examination. It has also been argued that an observed psychiatric long case allows examiners to compensate for differences in complexity across the case (15). Observation may therefore contribute to the reliability of the long case but there are no published data to support this.

Previous research using this history taking long case format has shown that, if different examiners rate the observation and presentation parts of the case, there is little correlation in the marks for the two parts (16). This suggests that the two parts measure different aspects of student performance. In this study we used the same examiner throughout the long case. Although this in itself may have introduced a judgmental "halo" effect, a more integrated appraisal of the candidate's interaction with the patients may have been achieved. Indeed, physicians appear to rate as well using global marking as checklists (7) and it may be that ours are more comfortable with the traditional non-check list format used for the long case presentation.

Thus, the inter-case reliability of two long cases alone does not provide a reliable examination. We conclude that those institutions using the long case should be encouraged firstly to observe the process and, secondly, to seriouslly consider increasing the number of cases. This study suggests that those searching for a different format to the OSCE for the assessment of final year clinical skills, need not necessarily abandon the concept of using real, unstandardised patients and long cases could be combined with the OSCE format. This does not preclude paying attention to potential bias in the use of cases whether they are standardised or real. However, our data do suggest that, given sufficient testing time, the long case cannot be abandoned on the grounds of reliability alone. The argument hinges on which of the two tests would provide the better test of clinical competence. More research is needed in this area. 


\section{References}

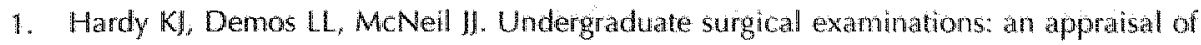
the dinical orals. Med Educ 1998; 32:582-9.

2. Van der Vleuten CPM. Making the best of the "long case". Lancel 1996; 347:704-5.

3. Ludbrook $L_{s}$ Marshall VR. Examiner training for clinical examnations Grit Med Educ $1971 ; 5: 152-5$.

4. Newble Dl, Hoare I, Sheldrake PF. The selection and training of examiners for clinical examinations Med Educ $1980_{;}^{*} 14: 345-9$.

5. Harden RM, Gleeson FA. ASME Medical Educational Booklet no. 8 Assessment of medical competence using an objective structured clinical examination (OSCE). Joumat of Medical Education 1979; 13:41-54.

6. Meadow R. The structured exam has taken over. BMI 1998; $317: 1329$.

7. Van der Vleuten CPM. The assessment of professional competence: Developments, research and practical implications. Adv in Heath Sci Educ 1996; 1:41-67.

8. Swanson DB, Norman GR, Linn RL. Performance-based assessment: Lessons learnt from the health protessions. Educational Researcher 1995; 24 (5):5-11.

9. Swanson DB. A measurement framework for performance based tests. In I.R. Hart \& R.M. Harden. (Eds). Further developments in assessing clinical competence 1987; pp 13-45. Montreal: Can-Heal.

10. Van der Vleuten CPM, Swanson DB. Assessment of clinical skills with standardised patients: State of the Art. Teach Learn Med 1 990; 25:224-9.

11. Brennan RL. Elements of generalisability Theory. American College testing Program. lowa 1983

12. Stillman P, Regan MB, Swanson D, Case S, MoCaha I, Feinblatt I et al. An assessment of the clinical skills of fourth-year students at four New England medical schools. Acad Med 1990; 65:320-6.

13. Olson LG. The ability of a long-case assessment in one discipline to predict students" periormance on long case assessments in other disciplines. Acad Med 1999; 74:835-9.

14. Newble DI. The observed long case in clinical assessment. Med Educ 1994; 25:369-73.

15. Price J, Byrne GJA. The direct climical examination: an alternative method for the assess. ment of clinical jasychiatric skills in undergraduate medical students. Med Educ 1994; $28: 120-5$

16. Wass $\mathrm{V}_{\text {, folly }} \mathrm{B}$. The long case: What does it measure? A comparison of obserwation and presentation of history taking in a traditionall long case within a final year OSCE. Med Educ 2001; $35: 729.34$ 


\section{Does observation add to the validity of the long case?}

\section{Dr Val Wass}

Department of General Praclice and Primary Care,

Guy's, King's and St Thomas' School of Medicine, London.

\section{Professor Birian Jolly}

Department of Medical Education, "The University of Sheffield.

\section{Published Medical Education $200135: 729-34$}

\section{Acknowledgements}

Dr John Rees and Professor Cwyn Williams for supporting this research within the finals clinical examination, Professor Cees van der Vleuten for his advice on analysing the study and Professor Roger Jones and Professor David Newble for their comments on the manuscript. 


\begin{abstract}
Background: A London medical school final MBBS examination for 155 candidates.

Objective: To investigate whether observing the student-patent interaction in a history taking (HT) long case adds incremental information to the traditional presentation component.
\end{abstract}

Design: A prospective study of a HT long case which included both examiner observation of the student-patient interview (part 1 ) and traditional presentation to different examiners (part 2). Checklist and global ratings of both parts were compared. Examinars were paired to estimate inter-rater reliability. The students also took a twenty station Objective Structured Clinical Examination (OSCE).

Outcome measures: Correlation of (1) examiner ratings for observation and presentation of the HT long case, (11) examiner pair ratings and (III) stepwise regression analysis of scores for the HT long case with OSCE scores.

Results: Seventy-five $(48.4 \%)$ candidates had two examiner pairs marking their case history. Observation and presentation scores correlated poorly (checklist 0.38 and global $0.33 \%$. Checklist and global scores for each part correlated at higher levels (observation 0.64 and presentation 0.61 ). Inter-rater reliability correlations were higher for observation (checklist 0.80 and globall 0.72 ) than for presentation (checklist 0.38 and global 0.63 ). When HT long case scores were correlated with OSCE scores, using stepwise regression, global presentation scores showed the highest correlation with the OSCE score $(0.36)$ and the global observation scone contributed a further $12 \%$ to the correlation $(0.50)$.

Conclusion: Observation of history taking in a long case appears to measure a usefuland distinct component of clinical competence over and above the contributhon made by the presentation. 


\section{Introduction}

The search for the ideal assessment of clinical competence for undergraduates, which is both valicl and reliable, remains controversial. (1) in the traditional long case, candidates are given uninterrupted and unobserved time, usually 30 to 45 minutes, to interview and examine a patient, selected from the wards or outpatients and untrained for examinations. Candidates then present their findings to the examiners as in an unstructured oral examination. The long case attempts to assess the integrated interaction between the doctor and a "real" patient. It is arguably a valid and educationally valuable test (2).

However, the assessment is lengthy and usually only one long case is used. The argument against the long case hinges on reliability. There is now indisputable evidence that in all measurements of clinical competence, candidates perform variably across tasks $(3,4)$. One case is insufficient to produce a reliable measure of the candidate's ability.

The introduction of the objective structured clinical examination (OSCE) (5), which uses multiple stations to produce a more reliable test format; enables isolated components of the long case to be examined in a variety of contexts. The use of this OSCE format improves reliability (6); consequently, many medical schools are turning towards this form of clinical competence testing. However, this move may take place at the expense of validity (1): It may be limited by its reductionist approach to clinical performance, as well as being time-consuming and costly. These last factors cannot be ignored.

Some UK medical schools have been reluctant to lose the long case as an assessment tool. The examination board of this London Medical School originally decided, when an OSCE was introduced in the final examination, that a long case using real patients should be included. It was agreed that assessment of the candidate's interaction with randomly selected real patients was important and that examiners should be able to cross-examine candidates in the traditional relatively unstructured way. Two modifications were proposed. Firstly that the physical examination of the patient should be excluded from the long case assessment as there were several clinical examination stations in the OSCE. Secondly, that the student"s interview with the patient should be observed.

The latter decision was important to us. Attempts have been made to improve reli. ability within a long case. Gleeson ( 7 ) developed the objective structured long examination record (OSLER) where the presentation is structured to increase the observations made by examiners on the candidate's approach to the case. 


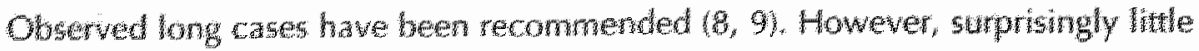

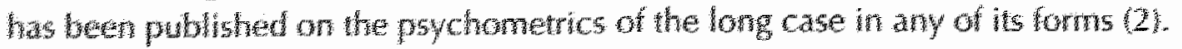

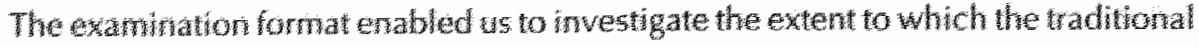

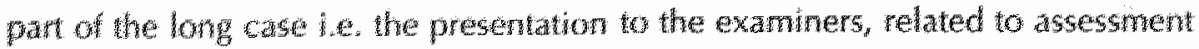

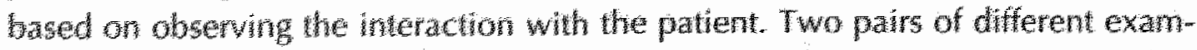
mers independenty ated the wown the observan and the presentation. mportant reseanch questions could be aked Dows observing the student-patient interacton add incremental infomation on clincal competence to the traditionat presutution component How wello independent rathgs for the wo components cortate? is the inter-rater relabity of the observed component beter than for the unobserved component. Is the combined rating of both parts beter than for the raditionat whobserwed one alone?

\section{Method}

The chncal examinations took place over thee days. The aim was to test clinical competerce. The candidates had atso taken thee writen papers of (a) multiple choice, (b) short answer and (c) essay questions.

The format of the cinical examination was:

\section{The history taking long case}

Candidates were given sixteen minutes (part 1) with a patient to elicit their full medical history, formulate diagnostic ssues and summarise their thoughts. They were not required to examine the patient. This was followed by an eight minute unstructured presentation of the case (part 2).

During part 1, the candidate was silently observed taking the history by one or two examiners. No interaction was allowed. The examiner(s) marked against a comprehensive checklist. The items covered by the checklist are summarised in Table 1. This list scored out of 20 for history taking. In addition a further 20 marks could be given, using a 1-5 Likert scale, as global ratings allocated for four parameters: medical history, psychosocial history, interviewing skills and overall fluency of the performance.

For part 2, the candidate moved on to present the case to one or two examiners in the traditional way. The examiners could ask unstructured questions, as in the usual long case format, to clarify the candidate's description and interpretation of the history and the conclusions reached. They marked independently using an identical checklist (20 marks) and global rating scheme (20 marks). Thus the assessment 
Table 1: Observation of the history taking long case: items covered by the checklist:

\begin{tabular}{|c|c|c|}
\hline Heading & llems & $\begin{array}{l}\text { Maximan } \\
\text { points } \\
\text { allocated }\end{array}$ \\
\hline Patient details & Appropriate introduction/age/ accupation & $\pi .0$ \\
\hline Present illness & $\begin{array}{l}\text { Symptoms: type, description, duration, alleviating, aggravating, } \\
\text { precipitating factors, previous episodes, medication, psychological } \\
\text { symptoms }\end{array}$ & 7.0 \\
\hline $\begin{array}{l}\text { Past medical } \\
\text { history }\end{array}$ & Past illness, medications, hospitalisation, allergies & 3.0 \\
\hline System review & $\begin{array}{l}\text { Micturition, appetite, weight, bowel function, menstruation if } \\
\text { appropriate }\end{array}$ & 4.0 \\
\hline Social history & Family history, housing, alcohol, tobacco, nutritional & 5.0 \\
\hline Total score & & 20.0 \\
\hline
\end{tabular}

of the candidate's presentation could be compared with the assessment of the actual observed interaction.

Patients: Medical, surgical and psychiatric patients were selected from hospital wards and outpatient departments. They were untrained for examinations and no attempt was made to standardise them. Two cases were alternated, wherever possible, at each of the long case stations. Candidates were assigned to patients at random.

The examiners: Provided numbers permitted, a team of twelve examiners per session (four per candidate) was allocated to the long cases. The examiners were consultants or senior lecturers, experienced in long case assessment in the usual "presentation only" format. Before the examination, they were briefed together for both parts of the assessment and instructed to mark independently and not collude or alter scores after discussion. Wherever possible, they worked in pairs. They were allocated by rota to examine on either part 1 or part 2 . In the course of a session. they had equal experience of examining both parts. If there were insufficient examiners to make pairs, the candidates were marked by one examiner only.

The OSCE examination consisted of twenty stations ( 8 minutes each) with one examiner per station. The stations included 8 testing physical examination, 4 assessing communication skills, 3 on practical skills and 5 on data and imaging interpretation. A single examiner rated each station. 


\section{Statistical analysis}

Data analysis was carried out using the Statistical Package for Social Sciences (SPSS). Mean scores on observation and presentation of the long case were calculated for all candidates. Mean examiner scores for those candidates marked by two examiners on both parts of the long case were correlated with marks for the observation and presentation using the standard (Pearson) product-moment correlation. The inter-rater reliability of the paired examiners was estimated on each part, using intra-class correlations, for both checklist and global scores The total OSCE scores for the candidates were correlated with the checklist and global scores using stepwise regression. The traditional long case score, i.e. the global presentation score, was entered first followed by the other component scores to investigate any contribution made to the variance in OSCE scores.

\section{Results}

One hundred and fifty five candidates took the examination. They were marked on the HT long cases by a team of fifty examiners who rotated to cover the three day examination. All candidates were rated by a different examiner on the observation part and the presentation part of one HT long case. Seventy five $(48.4 \%)$ candidates were rated by wo examiners on both parts. The performance of this "study group" of 75 candidates was analysed in detail.

To compare the study group (two examiners) with the non-study group (one examiner) a random selection of one examiner was made from the study group examiner pairs. Based on the scores of one examiner only, the mean total HT long case score (out of 80 ) for the study group was 56.8 5 SD 8.6 compared to $60.9 \pm$ SD 8.3 for the rest of the cohort. The study group scored statistically significantly lower $(p=<0.05$. $95 \%$ confidence interval (Cl) -6.73 to-1.36). The mean marks for the observation part were 14.5 (global) and 13.9 (checklist) for the study group and for the remaining cohort 15.7 (global) and 14.5 (checklist). The mean marks for the presentation part were 14.5 (global) and 13.9 (checklist) for the study group and for the remaining cohort 15.5 and 14.8 respectively. The range of SDs was $2.5-3.1$. All comparisons on the long case scores between the study group and the remaining cohort were statistically significant $(p<0.05)$. Mean OSCE scores were 259.7 ( 10.0 ) and $260.2( \pm 8.4$ ) for the study and remaining candidates respectively. This difference was not significant. There was also no difference between the study group and the remainder on any other part of the examination.

Correlation coefficients for the double marked study group are summarised in Table 2. 
Table 2: Correlation between mean (averaged across (wo examiners) for observation and presentation scores for all double marked candidates $(n=75)$.

\begin{tabular}{|c|c|c|c|c|}
\hline \multirow{2}{*}{$\frac{\text { Correlations }}{\text { (inter-rater correlation) }}$} & \multicolumn{2}{|l|}{ Observation } & \multicolumn{2}{|c|}{ Presentation } \\
\hline & Checklist & Gilobal & Checklist & Global \\
\hline & $(0.72)^{* *}$ & $(0.71)^{* * *}$ & $(0.38)^{* * *}$ & $(0.60) * *$ \\
\hline Observation Checklist & $1.00 t$ & $0.64 t$ & $0.38 t$ & $0.18+$ \\
\hline Observation Global & & $1.00 t$ & $0.25 t$ & $0.33+$ \\
\hline Presentation Checklist & & & $1.00+$ & $0.61 t$ \\
\hline Presentation Cilobal & & & & $1.00+$ \\
\hline
\end{tabular}

Intra-class** or standard Pearson th correlations were used as indicated

Table 3: Results of the stepwise regression of long case components on the OSCE scores and their significance.

\begin{tabular}{lllll}
\hline Step Variables entered & $\begin{array}{l}\mathrm{R} \\
\% \text { vartance } \\
\text { explained }\end{array}$ & $\mathrm{R}^{2}$ change & $\begin{array}{c}\text { Significance } \\
\mathrm{R}^{2} \text { change }\end{array}$ \\
\hline $1 \quad \begin{array}{l}\text { Presentation Global Rating } \\
\text { (PGR) }\end{array}$ & $.364 \quad 13.3 \%$ & .133 & .007 \\
$\begin{array}{l}\text { PGR and Obserwation } \\
\text { Global Rating } \\
\text { (OGR) }\end{array}$ & $.503 \quad 25.3 \%$ & .120 & .001 \\
$\begin{array}{l}\text { PGR, OGR and Observation } \\
\text { Check list Rating } \\
\text { (OCR) }\end{array}$ & $.503 \quad 22.2 \%$ & .001 & .778 \\
$\begin{array}{l}\text { PGR, OGR, OCR and Presentation } \\
\text { Check list Rating }\end{array}$ & $.510 \quad 26.0 \%$ & .007 & .427 \\
\hline
\end{tabular}

Intra-class correlations between examiners (inter-rater reliabilities) were higher for observation of the case $(0.72$ for checklist and 0.71 for global observed ratings) than for the case presentation 10.38 for checklist and 0.60 for global presentation ratings). Exarniner pair scores were then combined to compare ratings across the long case components for the 75 candidates. Within the separate observation and presentation components, checklist and global ratings showed Pearson correlation coefficients of 0.64 (observation) and 0.61 (presentation). There was a clear lack of correlation between scores given for long case observation compared to presentation using either checklist or global scores (Pearson correlations ranged from 0.18 to 0.38 ). 
Table 3 summaries the results of the regression analysis of the percentage variance contribution made by each part of the HT long case to correlation with the OSCE score and the significance (using a t-test, as produced as part of a SPSS standard output). The presentation global rating showed the highest individual correlation of 0.36 ( $p=0.001$ ) with the OSCE scores. Adding the observation score (globally rated) added significant explanatory power to the regression equation almost doubling the explained variance from $13 \%$ to $25 \%$ giving a correlation of $0.50(\mathrm{p}=0.001)$. Further inclusions did not increase the variance explained by these variables.

\section{Discussion}

The presentation of a history in the long case has been accepted as a measure of the canclidate's overall ability to carry out a medical interview, appraise the findings and decide a course of action. We have shown that examiners observing and marking the candidate during the, usually neglected, interaction with the patient rate the candidate differently. When taking the OSCE as a measure of clinical competence, direct observation of the HT long case contributed as much again as the presentation to the correlation of the $\mathrm{HT}$ long case with the OSCE results. This is, perhaps, not surprising but has never been demonstrated before in psychometric terms. It challenges the tradition of case presentations alone.

This study examined the history taking process of the long case only. Real patients were used and there was no attempt to standardise them. The candidate was not asked to carry out a clinical examimation. This was partly for reasons of time and also because clinical examination techniques were tested in the OSCE itself. However, the candidates were expected to process the information gathered from the patients to present to the examiner in the usual way.

The presentation was conducted in the traditional format, the examiners being free to ask the questions they perceived relevant in an unstructured way and then make general overall judgements. The introduction of a checklist to be completed at the presentation was part of the research design to assess comparability of the presentation and observation. As reported in the literature (10), checklist and global ratings correlated highly. Inter rater reliability was better for the observed part of the long case. The low examiner agreement on the checklist scores for the presentation tends to confirm the unstructured format of the presentation. The format was therefore as close as we could get to the complete long case. The crucial issue of observation versus presentation would hold with or without the clinical examination component. 
The study cohort performed slightly worse on the long case, but not on any other part of the examination. This may have been because the presence of another examiner made each more cautious in awarding marks. However the long case score ranges and distributions were not significantly different for the two groups. The difference in means scores would not affect the results of the study, which were generated entirely from within the study cohort.

The higher inter-rater reliability for the observed part of the case, compared to the presentation, throws doubt on relying on the presentation alone. In the latter, the examiners may be trying to make inferences about what had happened in the previous part. This may have contributed to the lower correlation of their scores. Thus further work is needed to assess the difference if the same examiners are used for both parts. However the fact that the ratings of observation and presentation correlated poorly and contributed significantly and independently to the correlation with clinical competence, as judged from the OSCE score, suggests that they measure different parameters of clinical competence.

Swanson (3) points out that all performance-based assessments within health professions confirm that testing examinees in realistic performance-based situations is fraught with difficulty. Complex interactions between the context (situationf task) and the construct (skill/knowledge) are being measured. Van der Vleuten has underlined these problems. He uses the complex cognitive psychological processes involved in professional clinical expertise (4) to explain the variability seen across different examination components and from context to context.

The failure to find a strong correlation between performance on the long case and the OSCE stations could be accounted for by one of two factors. The OSCE may measure a different clinical process. Alternatively, it may just reflect insufficient sampling in the use of only one long case. If extrapolations from other examinations are used, the latter may well be true. Swanson (11) calculated from oral examination case histories it would take a full day of testing with 12 to 16 cases to achieve an acceptable level of generalisability for a high stakes examination. Stillman (12), using standardised patients as both subjects and examiners, showed that 13 and 17 cases were needed to achieve reliability scores of 0.68 and 0.88 respectivelly. Further work is clearly necessary to estimate the sampling errors of long cases, as we can no longer assume that the long case, even if observed, is an equivalent process to a clinical viva (13).

We conclude that the traditional long-case presentation becomes a more valid measure of the candidate's clinical competence if the interaction with the patient is observed. This conclusion has direct relevance to the use of long cases in clinical examinations but may also has relevance to traditional case presentations an ward 
rounds. In the clinical setting, students present histories on ward rounds but are not generally observed while they interview patients. More attention to observation during ward clerkships may therefore be necessary. 


\section{References}

1. Meadow R. The structured exam has taken over. BM/ 1998; 317:1329.

2. Van der Vleuten CPM. Making the best of the "long case". Lancet, 1996; 347:704-5.

3. Swanson DB, Norman GR, Linn RL. Performance-based assessment: Lessons learnt from the health professions. Educ Res 1995;24(5):5-11.

4. Van der Vleuten CPM. The assessment of professional competence: Developments, research and practical implications. Adv Health Sci Educ 1996; 1:41-67.

5. Harden RM, Gleeson FA. ASME Medical Educational Booklet no. 8 Assessment of medical competence using an objective structured clinical examination (OSCE) / Med Educ 1979; 13:41-5.4.

6. Newble D I, Swanson D B. Psychometric characteristics of the objective structured clin. ical examination. Med Educ 1996; 22:325-34.

7. Gleeson $F$. The effect of immediate feedback on clinical skills using the OSLER. In: AI. Rothman \& $\mathbb{R}$ Cohen (Eds.). Proc. of the sixth Otawa conference of medical education 1994; 412-15. Toronto: University of Toronto Bookstore Custom Publishing.

8. Newble DI. The observed long case in clinical assessment. Med Educ 1994; 25:369-73.

9. Price I, Byrne GJA. The direct clinicall examination: an alternative method for the assessment of clinical psychiatric skills in undergraduate medical students. Med Educ 1994; 28:120-5.

10. Regehr G, MacRae H, Reznick R, Szalay D. Comparing the psychometric properties of checklists and global rating scales for assessing performance on an OSCE-format examination. Acad Med 1998; 73(9):993-7.

11. Swanson, D.B. (1987) A measurement framework for performance based tests. In I.R. Hart, \& R.M. Harden. (Eds). Further developments in assessing clinical competence. (pp 13-45). Montreal: Can-Heal.

12. Stillman P, Regan MB, Swanson D, Case S, MCCaha J, Feinblatt I et al. An assessment of the clinical skills of fourth-year students at four New England medical schools. Acad Med 1990; 65:320-6.

13. Hardy K.J, Demos LL, MCNeil JJ. Undergraduate surgicall examinations: an appraisal of the clinicall orals. Med Educ 1998; 32:582-9. 


\section{Achieving acceptable reliability in oral examinations: an analysis of the Royal College of General Practitioners Membership Examination's Oral Component.}

Val Wass

Senior Lecturer in General Practice

Department of General Practice and Primary Care,

Guy's, King's and St Thomas' School of Medicine, London.

\section{Richard Wakeford}

University Staff Development Officer

University of Cambridge

\section{Roger Neighbour}

Convenor of the Panel of Examiners, Royal College of Generall Practitioners, London

\section{Cees Van der Vleuten}

Professor of Education,

Department of Educational Development and Research,

University of Maastricht, Netherlands

Published in Med Educ $2003 ; 37: 126-31$

\section{Acknowlledgements}

Mike Thirlwall, the current convenor of the MRCGP orals and all members of the 1998 oral development group: Douglas Dare, Graham Sherwood, Richard Jones, Ros MacLintock, Simon Street, Carl Whitehouse and Gavin Young. John Foulkes, consultant to the panel, Tom Dastur, current examination administrator, Professor David Haslam chair of the Examination Board and the entire examining panel who conducted the orals. 


\begin{abstract}
Background:The Membership Examination of the Royal College of General Practice (MRCGP) uses structured oral examinations to assess candidates' decision making skills and professional values.

Aim: To estimate three indices of reliability for these orals.

Method: In summer 1998 a revised system was introduced for the orals. MRCGP 62 candidates took wo, 20 minute (five topic) orals with two examiner pairs. Areas for oral topics had been identified. Examiners set their own topics in three competency areas (communication, professional values and personal development) and four contexts (patient, teamwork, personal, society). They worked in wo pairs (a quarteb to preplan questions on ten topics. The results were analysed in detail. Generalisability theory was used to estimate three indices of reliability: (a) inter-case (b) pass/ail decision and (c) standard error of measurement (SEM). For each index, a benchmark requirement was preset at (a) 0.8 , (b) 0.9 and (c) 0.5 .
\end{abstract}

Results: There were 896 candidales. Eighty seven candidates (9.7\%) failed. Total score variance was attributed $10: 41 \%$ candidates, $32 \%$ oral content, $27 \%$ examiners and general eror. Reliability coefficients were (a) inter-case 0.65, (b) pass/fail 0.85. The SEM was 0.52 i.e. precise enough to distinguish within one unit on the rating scale. Extending testing time to four 20 minute orals, each with wo examiners, or five orals, each with one examiner, would improve inter case and pass/fail reliabilities to 0.78 and 0.94 respectively.

Conclusion: Structured orals can achieve reliabilities appropriate to high stakes examinations if sufficient resounces are avalable. 


\section{Introduction}

Oral examinations have been widely used in undergraduate and postgraduate examinations in the UK $\mathrm{K}_{r}$ including those for membership of medical royal Colleges. These are examiner / examinee encounters where topics unrelated to specific patients are discussed. In recent years the validity and reliability of oral examinations has come under scrutiny and there is an increasing tendency to drop them from assessment procedures (1-3). Some institutions, especially the Royal Colleges, have chosen to retain oral examinations as they feel these add a unique, important and valid dimension to their assessment procedures.

The examination panel for the MRCGP considers that a face to face encounter with a candidate is an important part of the process of College entry (4). The MRCGP examination is now taken in modular form: the oral must be passed separately from the other components. They aim to assess the candidate's decision-making skill and professional values; a process examined less comprehensively in the written and consulting skills components of the examination. Candidates take two orals, each of twenty minutes, and with a pair of examiners. Examiners are selected and trained. Their performance is regularly monitored and feedback given (5). Technical difficulties in achieving fairness for candidates of different ethnicity (for example) have been investigated $(6,7)$ and are addressed in training.

Examiners learn to structure orals, deliver them and make judgements using their own personal questions, but these are not standardised across the panel. Examiners remain autonomous and responsible for their own questions.

This policy raises two important questions. Firstly, how should examiner pairs structure and select questions to ensure the oral content samples as widely as possible across all areas of primary care? The variation in performance of candidates across cases is an important issue in clinical competence testing. Doctors do not perform consistently from task to task (8). A good performance on one question does not necessarily predict a good performance on the next. Thus broad sampling across primary care contexts is essential to assess the candidate adequately. It follows that examiners must ask as many questions as possible, in a given time, and ensure against subject repetition or overlap. They must be sure that, as soon as judgements are made, a new question is asked in a different area. Orals should therefore be planned very carefully.

Secondly, concerns exist about the reliability of the oral examination i.e. the reproducibility of oral scores. This applies more to candidate performance across cases or questions (inter-case reliability) than to the consistency of examiner pair ratings (inter-rater reliability). In any examination, the true score of candidate 
performance is affected by many factors: differences in examiner judgements, the cases used, candidate nerwousness and test conditions. Estimating the reliability of orals, where questions are not the same for all candidates and a large number of examiners are employed, is more complicated than for written papers where all candidates answer the same questions marked by a rellatively small cohort of examiners. Classical test theory, often used to estimate written paper reliability, cannot control for all these variables. An alternative method, using generalisability theory, can. This methodology allows expression of multiple reliability indices. It also explones how the differences in error variance, due to a variety of questions and multiple raters, relate both to each other and to true variance in candidate perfor. mance (9). The ability to handle multiple sources of error is a key advantage of generalisability theory, but a comprehensive database is essential for this analysis to be carried out. This must identify both individual tem scores and the examiners responsible for each score.

Two Canadian studies of oral certification examinations have demonstrated acceptable inter-rater reliabilities $(10,11)$. There is little published work on the inter-case reliability of orals using generalisability theory. Tumbull (11) estimated reliability across two oral sessions and reported low coefficients $(0.30-0.47)$. Swanson (12) calculated, using data based on 30 minute orals per case history with one or two examiners, that it would take two hours and four pairs of examiners to achieve an acceptable level of reliability (0.78) or four hours divided between eight individual examiners (0.82). His data suggests that the length of testing time required to ensure this level of inter case reliability is three times that used by the MRCGP.

In June 1998 the orals became, for the first time, a modular "stand alone" component. The reliability of the pass/fail decision thus is of paramount importance to the new examination. Bearing these issues in mind, the RCGP Examination Board decided to restructure the orals to ensure preplanned comprehensive testing across a defined range of contexts. A comprehensive database was established from which to estimate both the inter-case and pass/fail reliability of the orals using generalisability theory. The aim was to predict the optimum grading arrangement (i.e. a mean of item scores or overall examiner global rating) and the examination format required to achieve the reliability necessary for a high stakes examination.

\section{Method}

\section{Situcture of the orals prior to 1998}

The orals are blueprinted within the MRCGP examination to assess candidate's decision-making skills. The examining panel of approximately $150 \mathrm{UK}$ general practitioners convenes annually for a three day planning and training workshop. In 
1997 the panel used a modified Delphi technique wo define areas of primary care they felt provided the key contexts in which to test decision making skills. The themes identified were communication, professional values and personal and professional development in contexts of patient care, working with colleagues, society and personal responsibility. Examiners construct their own questions on these topics.

The oral arrangements prior to 1998 have been fully reported elsewhere (5). MRCGP candidates take two consecutive orals with a short break in between. Each oral is conducted by two examiners, selected from different geographical regions, who examine together throughout the day. New examiners work with experienced ones and candidates are assigned to examiners from regions other than their own. Examiners are selected and trained (5).

In the past each oral lasted thirty minutes. The two examiners alternately asked their own questions of approximately five minutes each. Both examiners recorded a mark for every question using a nine point scoring scale from "outstanding" to "dangerous". Figure 2 gives the verbal descriptions used to award these grades. On completing the oral, the examiners agreed a final global score for the candidate's performance using the same nine-point scale. The two final scores for each oral were averaged to achieve the final score; a bare pass being the minimum acceptable pass score. All components were taken at the same time and it was possible to compensate on marks across the papers.

\section{Changes introduced into the oralls in June 1998}

At the 1998 examiners' workshop the plans to change the orals in anticipation of modularisation of the MRCGP were introduced and examiner training was given. Changes consisted of:

- A cut in oral length from 30 to 20 minutes to allow examiner preparation time.

- A cut in question length from five to four minutes i.e. a minimum of five topics per oral.

- A planning blueprint grid to ensure a wide spread of topics and no content overlap in the two orals. Figure one shows a sample grid used to plan a 20 minute oral.

- Preplanning of orals: Two examiner pairs worked as quartets throughout a morning or afternoon session. Each candidate was allocated to a quartet. At the start of the day, half an hour was timetabled for examimers to agree and discuss ten topics to be used throughout the session.

- Collation of independent examiner ratings: The previous marking schedules were not changed and the two examiners continued to alternate asking questions recording a mark for both their own and their partner's topics. They were asked to mark independently and without collusion. On completing the oral, each 
Figure 1: The oral planntyg grid: Example pan for 20 minute oral

\begin{tabular}{|c|c|c|c|}
\hline Competency area & Communication & $\begin{array}{l}\text { Professional } \\
\text { walues }\end{array}$ & $\begin{array}{l}\text { Personal and } \\
\text { professional } \\
\text { growth }\end{array}$ \\
\hline Care of patients & $\begin{array}{l}\text { Strategles for } \\
\text { breaking bad news }\end{array}$ & & \\
\hline Working with colleagues & & $\begin{array}{l}\text { What enalbles a } \\
\text { Primary Health } \\
\text { Care Team to } \\
\text { work well? }\end{array}$ & \\
\hline Society & & $\begin{array}{l}\text { Access to medical } \\
\text { records }\end{array}$ & \\
\hline Pensonal responsibulty & $\begin{array}{l}\text { Tackling burmout in } \\
\text { a colleague }\end{array}$ & & $\begin{array}{l}\text { Personal plans for } \\
\text { reaccredidation }\end{array}$ \\
\hline
\end{tabular}

Figure 2: Marking grades

\begin{tabular}{|c|c|}
\hline Giade & Description \\
\hline O Outstanding & $\begin{array}{l}\text { A very rare candidate. Uniformly outstanding. Well read, coherent, rational, } \\
\text { consistent, and crittical. Without being asked, justifies approaches, etc, by } \\
\text { tererence to the literature. }\end{array}$ \\
\hline E Excellent & $\begin{array}{l}\text { Extremely impressive candidate. Cenerally outstanding candidate but not so } \\
\text { uniformly well informed. }\end{array}$ \\
\hline G Good & $\begin{array}{l}\text { Impressive candidate. Well informed, coherent decisions, farlly critical. } \\
\text { Justifies majority of approaches well. }\end{array}$ \\
\hline S. Satisfactory & $\begin{array}{l}\text { A candidate characterised lby a solidness liather than impressiveness. Able to } \\
\text { justify only some decisions well, but most decisions appear adequate. }\end{array}$ \\
\hline B Bare Pass & $\begin{array}{l}\text { Examiner is only just comfontable with candidate's adequacy. Not much } \\
\text { justification of decisions, but important ones are sensible. Decision making } \\
\text { and other skills are just, on balance, acceptable. }\end{array}$ \\
\hline \multicolumn{2}{|l|}{ Prss/fall boumdary } \\
\hline N Nol adequate & $\begin{array}{l}\text { Questionable approaches sometimes meither justifiable nor justified. } \\
\text { Examine is uncombortable with candidate and his or her decision making } \\
\text { skills. Unadequate at applying basic principles }\end{array}$ \\
\hline U Unsatisfactory & $\begin{array}{l}\text { Approaches are often inconsistent and rarely justified. Candidate does not } \\
\text { seem to be capable of perfoming a MRCGP level. Clearly poor at applying } \\
\text { basic } \\
\text { principles. }\end{array}$ \\
\hline P porr & $\begin{array}{l}\text { Candidates clearly not passable, though slight evidence of ability. Generally } \\
\text { incoherent approach to practice. No justification for specific approaches. }\end{array}$ \\
\hline D.Dangerous & $\begin{array}{l}\text { Candidate worse than "poor". Adopts such arbitrary approaches as to put } \\
\text { patients at risk. }\end{array}$ \\
\hline
\end{tabular}


examiner independently recorded a global score for the candidate's performance as before.

- The pass/fail score was set at a minimum of four "bare passes" (figure 2),

- Quartets met after each pair of oral sessions to discuss candidate ratings for the two orals. Individual examiners could move global scores up but not down.

- Training was given on completing the forms to ensure comprehensive data collection.

\section{Data collection}

Examiners' five individual topic and final global scores were manually entered into a Statistical Package for Social Sciences (SPSS) database. This was used for the subsequent analysis. Verbal scores were converted to numerical scores: outstanding 9 , excellent 8 , good 7 , satisfactory 6 , bare pass 5 , not adequate, 4 , unsatisfactory 3 , poor 2 , dangerous 1 .

\section{Statistical Analysis}

Descriptive statistics were carried out using SPSS. A two-facet general isability analysis (9) was performed with examiners and orals as facets (orals nested within candidates and examiners nested within orals and candidates; all random model). Subsequently three reliability indices were estimated as projections for different numbers of orals and examiners.

The three reliability indices estimated were:

1. The inter-case reliability: This was estimated as a regular general isability coefficient or, more appropriately, a dependability coefficient. A customary but arbitrary benchmark for a minimally acceptable inter case reliability score is $0.8(13)$.

2. Pass/fail decision reliability: This reliability index was estimated by including information on whether the scores exceeded the pass / fail scores or not (14). This is an accepted alternative to just estimating reliability from the scores alone. The benchmark set for minimum acceptable reliability for this index was 0.9 as it was felt that it is a more critical measure.

3. Standard error of measurement (SEM): The confidence limits of the individual's test scores were estimated on the original scoring scale using this. To determine a $95 \%$ confidence limit, the SEM score was multiplied by 1.96 . As in this examination, each scoring unit of should be $95 \%$ confident, the benchmark for the minimally acceptable SEM score was set at 1/1.96 i.e. 0.51. Values below this were considered acceptable. 
Table 1: Etimates of the contribution made to the overal variance by the examination components: examineses, oral topics and examiners.

\begin{tabular}{llll} 
Source of variation & $\begin{array}{l}\text { Estimated variance } \\
\text { component }\end{array}$ & $\begin{array}{l}\text { Standard error } \\
\text { Examineess }\end{array}$ & $\begin{array}{l}\text { Percentage of } \\
\text { form wariance }\end{array}$ \\
Oral topics: Examinees & 0.38 & 0.038 & $40.7 \%$ \\
Examiners: Oral topics: Examinees & 0.32 & 0.026 & $32.2 \%$ \\
Total & 1.18 & 0.010 & $27.1 \%$ \\
\hline
\end{tabular}

Table 2: Estimated reliabil ity coefficients for inter case reliability $(A)$, passfail decision reliability (B). and standard error of measurement $(C)$ as a function of testing time and number of examiners.

\begin{tabular}{|c|c|c|c|c|c|c|c|c|c|c|}
\hline \multirow{2}{*}{$\begin{array}{l}\text { Number } \\
\text { Oralls }\end{array}$} & \multirow{2}{*}{$\begin{array}{l}\text { Trasting } \\
\text { Time }\end{array}$} & \multicolumn{9}{|c|}{ Number of examiners } \\
\hline & & \multicolumn{3}{|l|}{1} & \multicolumn{3}{|l|}{2} & \multicolumn{3}{|l|}{3} \\
\hline & (minutes) & A & $B$ & $\mathrm{C}$ & A & $B$ & C & A & $\mathrm{B}$ & C \\
\hline 1 & 20 & 0.41 & 0.70 & 0.84 & 0.48 & 0.74 & 0.73 & 0.50 & 0.76 & 0.70 \\
\hline 2 & 40 & 0.59 & 0.82 & 0.59 & 0.65 & 0.85 & 0.52 & 0.67 & 0.87 & 0.49 \\
\hline 3 & 60 & 0.68 & 0.87 & 0.48 & 0.73 & 0.89 & 0.42 & 0.75 & 0.91 & 0.40 \\
\hline 4 & 80 & 0.74 & 0.90 & 0.42 & 0.78 & 0.92 & 0.37 & 0.80 & 0.93 & 0.35 \\
\hline 5 & 100 & 0.78 & 0.92 & 0.37 & 0.82 & 0.94 & 0.33 & 0.83 & 0.94 & 0.31 \\
\hline
\end{tabular}

Key: $A=$ =nter case reliability. Benchmark 0.8, B = Pass/fail reliability Benchmark 0.9, C = SEM Benchmark 0.5 Emboldened entries approximately exceed the acceptable benchmarks set for each reliability index.

The reliability studies were repeated twice using first the global and then the averaged mean scores.

\section{Results}

Mean scores: Eight hundred and ninety six candidates took the oralls and $87(9.7 \%)$ candidates failed. Almost three quarters $(72.2 \%)$ of the candidates were UK trained doctors completing their vocational training programme; the rest had completed training before 1998 apart from 12 candidates from overseas.

One hundred and forty one examiners were involved. The mean grade for the averaged five individual topic scores was 6.0 (standard deviation (SD) 0.87 ; range 
3.25-8.25). The mean global score was 6.0 (SD 0.72 ; range 3.25-8.25). The agreement between mean topic grades and mean final global scores was very high (correlation coefficient 0.98 ). The correlation coefficient between candidates" performance across the two orais was 0.43 .

Variance components:As the global and averaged topic scores correlated at such a high level, results for the generalisability analysis of global scores only are reported. Table 1 summarises the contribution made to the overall variance by the examination components. Total variance was attributed as follows: $41 \%$ for candidates, $32 \%$ for oral content and $27 \%$ for examiners.

Generalisability analysis: Table 2: summarises the actual and predicted reliability coefficients according to testing time and number of examiners for the three reliability indices estimated i.e. inter case (A), pass/fail decision (B) and SEM (C).

\section{Discussion}

The advantage of using generalisability theory to estimate the inter case and pass/fail reliability coefficients is that these are independent of the scoring scalle and allow ready comparison with other studies. Our results are comparable with those of Swanson (12). He used case studies examined in oral format rather than the topics independent of specific case scenarios used in the MRCGP orals. However, benchmarking is rather arbitrary and we have set our own for the reliability indices used for the pass/fail decision. The SEM is dependent on the scoring scale which hinders cross study comparison. However, it is easier to set a defensible maximal acceptable value using confidence limits and it is for this reason that we chose to do this.

The comparison of three indices of reliability for the MRCGP orals has produced important results. The overall pass rate for the orals was high $(90.3 \%)$. The generalisability study shows that the reliability coefficient for the pass//ail decision would reach the preset benchmark of 0.9 if the orals were extended to include a further 20 minutes (fifteen rather than ten topics) with two further examiners (six rather than four judges).

On the other hand, to achieve the generally acceptable inter-case reliability of 0.8 , the oral structure would need revision. Extending the length of testing time and number of topics impacts more on the reliability than increasing the number of judges. Four 20-minute orals with 2 examiners (twenty topics with eight examiners) or five 20-minute orals with one examiner (twenty five topics with five examiners) would be required to achieve this benchmark. Increasing the examiners from two to 
three for each of the current orals has little impact. The reliability coefficient would only improve from 0.65 to 0.67 . In the current situation, with the same resources, using four examiners, each assessing one single twenty minute oral would be a better model in terms of improving inter-case reliability. There is in theory relatively little benefit to using examiners to double mark. Swanson came to the same conclusion (12). It is becoming increasingly apparent that, whatever the test format used the length of the test and hence breadth of topics covered impacts most on the reliability of a test (13).

Our standards for the reliability of the oral component of the MRCGP were set against customary, albeit rather arbitrary, standards. The use of confidence limits enabled us to make a more independent judgement on the fairness of the pass / fail decision and confirm that this is just about acceptable. The results overall are encouraging. The study demonstrates that provided an adequate length of testing time is given and sufficient independent judgements are made on a wide range of topics, orals can be made psychometrically acceptable.

The MRCGP has continued to develop the orals since these changes were introduced. Issues of cost to the candidate and feasibility remain of paramount importance. There is a move towards standardising questions to improve inter case reliability. As was the experience in both Israel (15) and Canada (11), this has to be introduced carefully. Examiners are used to the autonomy of generating their own questions. Increased examiner training in equal opportunities and clarity of question setting has also been introduced. Our results demonstrated that examiner performance contributed to $27 \%$ of the variance seen in the examination at the time of this study. Our study of reliability of the orals has highlighted the importance of these measures. All institutions using orals in high stakes assessments should be encouraged to do likewise. 


\section{References}

1. Wakeford R. Report of the survey of undergraduate medical education 1990. In: Centart policies. Vol. 1. London: General Medical Council; 1992:53-4

2. Wakeford RE, Belton A, Matsch I, Norman GR, Rainsberry P. Symposium: development of oral examinations as part of specialist certification examinations- an intemational perspective. Proceedings of the annual conference on research in medical education. Washington DC: Association of American Colleges, 1986:339-46

3. Thomas CS, Mellop C, Callender J, Crawshaw J, Ellis PM, Hall A. The oral examination: a study of academic and mon-academic factors. Med Educ 1993; 27:433-9

4. Wass V. The Orals. In: The MRCGP Examination. Moore R (Ed), Royal College of General Practitioners, London 2000:137-50

5. Wakeford $R$, Southgate $L$, Wass $V$. Improving oral examinations: selection, training and monitoring of examiners for the MRCGP. BM/ 1995; $311: 931-5$

6. Wakeford R, Farooqui $A$, Rashid A, Southgate L. Does the MRCGP discriminate against Asian doctors? BM/ 1992; 305:92-4.

7. Roberts $C_{*}$ Sarangi $S$, Southgate $L$, Wakeford R, Wass V. Education and Debate: Oral examinations - equal opportunities, ethnicity, and fairness in the MRCGP. BMI 2000; 320:370-4.

8. Swanson DB. A measurement framework for performance based tests. In 1.R. Hart, \& R.M. Harden. (Eds). Further developments in assessing clinical competence. (1987) (pp 13-45). Montreal: Can-Heal.

9. Brennan RL. Elements of generalisability Theory. American College resting Program, lowa 1983.

10. McLean LD, Dauphinee WD, Rothman A. T The oral examination in internal medicine of the royal college of physicians and surgeons of Canada: a reliability analysis. Annals of RCPS (C) 1988;21:510-44.

11. Turmbull J, Danoff D, Norman G. Content specificity and oral certification examinations. Med Educ 1996; 30:56-9.

12. Swanson DB, Norman GR, Limn RL. Performance-based assessment: Lessons learnt from the health professions. Educational Researcher 1995; 24 (5):5-11.

13. Wass $V$, Vleuten van der $C$, Shatzer J, Jones R. Assessment of clinical competence. Lancet $2001 ; 357: 945-9$.

14. Bremnan RL. Elements of generalisability Theory. American College testing Program, lowa 1983; pp 108.

15. Weingarten MA, Polloack MR, Tabenkin H, Kahan E. Variations among examiners in family medicine residency board oral examinations. Med Educ 2000; 34:13-7. 
Performance differences of medical students from ethnic minorities in a final medical school Objective Structured Clinical Examination: is there potential for bias in communication skills testing ?

\section{Dr Val Wass}

Senior Lecturer in General Practice

Department of Generall Practice and Primary Care,

Guy's, King's and St Thomas' School of Medicine, London.

\section{Dr Celia Roberts}

Senior Research Fellow

Department of Education and Professional Studies

King's College, London.

\section{Ron Hoogenboom}

Research Assistant

Department of Educational Development and Research.

University of Maastricht, Maastricht, Netherlands.

\section{Professor Roger Jones}

Wolfson Professor of General Practice

Department of General Practice and Primary Care,

Guy's, King's and St Thomas' School of Medicine, London, UK

\section{Professor Cees Van der Vleuten}

Professor of Education.

Department of Educational Development and Research,

University of Maastricht, Maastricht, Netherlands.

Published BMI 2003; 326: 800-3.

\section{Acknowledgements}

This study was supported by a grant from the King's Fund. Stevo Durbaba, Phill

Doulton of Professional Role Play LId and Nora Edmead gave invaluable assistance. We thank all the students and examiners who so kindly co-operated with this study. 


\begin{abstract}
Background: Students from ethric minorites may perform less well in medical exammations. Any bias in examination process must be identified and understood.
\end{abstract}

Aim: To assess the effect of ethricity on student performance in communication skills stations within an Objective Structured Clinical Examination (OSCE).

Setting: A final UK clinical examination consisting of a two-day, 22 station OSCE.

Method: An independent wo-sample T-test was used to examine relationships between ethnicity and student performance in nine clinical, five practical and six communication skills stations. Four OSCE stations, assessing communication sensilive to cultural issues, were analysed using video recordings to detect overt discrimination and misunderstandings. Twenty eight interactions were transcribed and analysed using discourse analysis.

Results: Mean performance (t standard deviation) for thnic minority (EM) students $(n=82)$ compared to white majority (WM) students $(n=97)$ was significantly lower for communication skills stations on day $167.0 \pm 6.8 \% \mathrm{EM}, 72.3 \pm 5.5 \% \mathrm{WM} p=0$ $001)$ and day $2(65.2 \pm 6.6 \% \mathrm{EM}, 69.5 \pm 6.3 \% \mathrm{WM} p=0003)$. No significant examples of overt discrimination were found in 309 video recordings. Transcriptions revealed subtle differences in communication styles in some poorly performing EM students. Examiners" assumptions about "good" communication may have comtribwed to grading differences in the cohort as a whole.

Conclusion: Explicit discrimination was not identified. A small group of male EM students used particularly pootly rated communicative styles and some subtle problems in assessing communication skills may have untroduced bias. Issues of diversity in lest construction and implementation must be addressed to ensure ethnic minority candidates are not disadvantaged. 


\section{Introduction}

Students from ethnic minorities are reported to perform less well overall than white candidates in both undergraduate $(1,2)$ and postgraduate $(3,4)$ medical examinations. Any form of potential racial discrimination within our examination systems is a cause for concern $(5,6)$. Problems with complex discourse may disadvantage candidates trained overseas in oral examinations (7) but there is little further published work on the impact of ethnic differences on examination performance. This is becoming an increasingly important issue in undergraduate assessment. Fairness and consistency of assessment across UK medical schools is crucial (8). We need to understand any source of potential bias which may lead to racial disad. vantage when developing tests for these skills.

When looking for potential discrimination within examinations, standardisation is a key issue; the more standardised the content, the less the potential for bias. Objective structured clinical examinations are currently most frequently used to assess undergraduate skills $(9,10)$ and include standardised simulated scenarios to test communication skills. Yet it is still difficult to achieve true objectivity $(11,12)$. However carefully designed, the scenario presented to candidates will vary since neither simulated patient nor candidate are speaking from scripts. Examiners and simulated patients make judgements based on an impression of how well the candidate managed the consultation. This judgement in turn, will be informed by their assumptions about what makes an effective consultation (13).

Given our concerns that some ethnic minority students do less well in final examinations, is there any evidence that they are disadvantaged by a bias in the marking? We report a study carried out within a final year OSCE designed to shed light on the potential to disadvantage students from ethnic minorities, with a particular focus on communication skills stations.

\section{Method}

Setting: The study took place in lune 1999 during the Final MBBS examination of the Cuy's and St Thomas' (since merged with Kings) Medical School.

\section{Examination structure}

A three and half hour OSCE conducted over two days, consisting of two long case history taking stations (21 minutes each) and 20 seven minute stations: nine clinical examination, six communication and five practical skills. Stations were similar but 
not identical on the two days. Simulated patients (SPS) were professionally trained to standardise the scenarios used on communication stations.

A different examiner marked each station against a checklist and gave a final five point global rating for overall clinical competency. SPIs awarded a five point global rating for overall communication skills independent of the examiner. All examiners and $S P_{5}$ had been briefed on the procedure. A minimum competence score for each station was set in advance using the Angoff standard setting method.

\section{Study design}

Each day, we selected two communication scenarios using rolle-players from different ethnic backgrounds (Figure 1). Informed verbal consent for video recording was given by all students. The local research ethics committee approved the study. Details of students' ethnicity were made available after the examination.

\section{Quantitative analysis}

The students were grouped as White, Asian to inclucie Indian, Pakistani, Bangladeshil and Asian other), Chinese, Afrom Caribbean and Other. For the purpose of this study, all ethnic minority candidates were categorised as one group: "Ethnic minorities" (EM) group and all other candidates as: "White majority" (WM). Mean station performance for each day was analysed on (a) all 22 stations (b) stations grouped by communication, practical, clinical skilis and long cases (c) the specific

Figure one:

\begin{tabular}{|c|c|c|}
\hline Day 1 & Stanioni 8 & Stathon 18 \\
\hline Day & $\begin{array}{l}\text { Dxplair to a rather obstinate, elderly. } \\
\text { midde class white woman that her } \\
\text { chest X-ray showed a possble lumg } \\
\text { metastasis. Bronchoscopy hat been } \\
\text { recommended. She dented that the } \\
\text { cancer may have returned and just } \\
\text { wanted antibiotics for her cough. }\end{array}$ & $\begin{array}{l}\text { Take a sexual history from a young } \\
\text { Muslim student who had had unpro- } \\
\text { tected casual sex at a party. She was } \\
\text { concerned she might have caught } \\
\text { something. She felt very upset about } \\
\text { this accidental break with her cultural } \\
\text { tradition and loss of her virginily. }\end{array}$ \\
\hline Daty 2 & $\begin{array}{l}\text { Assess a chinese businessman who } \\
\text { has come for the results of liver func- } \\
\text { ton tests. These indicate he nay be } \\
\text { drinkmg too much. This rollewayer } \\
\text { was asked to present himself as not } \\
\text { entirely fluent im English. }\end{array}$ & $\begin{array}{l}\text { Wegotiate with a young Afro-Carib } \\
\text { bean man who wants methadone } \\
\text { script because he says he has lost the } \\
\text { one given to him at the drug rehabili- } \\
\text { lation centre. }\end{array}$ \\
\hline
\end{tabular}


Table 1: Analysis of ethnicity by gender and age for the 175 candidates of known ethnicity

\begin{tabular}{lccccc}
\hline Ethnicity & Male & Female & $\begin{array}{c}\text { Mean Age } \\
\text { (years) }\end{array}$ & $\begin{array}{l}\text { Age (years) } \\
\text { range }\end{array}$ & $\begin{array}{l}\text { Total (percen- } \\
\text { tage) }\end{array}$ \\
\hline White & 50 & 47 & 24.6 & $23-32$ & $97(58 \%)$ \\
Asian & 21 & 21 & 23.8 & $22-26$ & $42(16 \%)$ \\
Chinese & 10 & 6 & 24.5 & $23-30$ & $16 \quad(6 \%)$ \\
Afro-Caribbeam & 1 & 4 & 25.6 & $23-32$ & $5(5 \%)$ \\
Other & 6 & 9 & 24.2 & $23-29$ & $15(13 \%)$ \\
& 88 & 87 & 24.4 & $22-32$ & $175(100 \%)$ \\
\hline
\end{tabular}

a** Indian, Pakistani, Bangladeshi and Asian other

"study" stations. An independent two-sample T-test was used to examine relationships between student performance and their ethnicity. $P$ values $>0.01$ were regarded as non-significant (NS). The reliability of each OSCE was calculated using Cronbach's alpha.

\section{Qualitative analysis}

All video recorded encounters were viewed as well as recorded comments made by SPS and examiners after candidates had left the station. The interaction length, candidate ethnicity and observations made during the viewing were recorded on a standard form. An assessment was made of the extent to which SPS and students established a relatively patient-centred encounter. Any potential misunderstandings, false assumptions or explicit discriminatory behavour were noted. The analyst (CR) wiewed the encounters "blind", allocating grades and comparing these after the viewing with SP and examiner ratings. Discrepancies between analyst, $S P$ and examiner were recorded.

These records were used to select specific interactions for detailed transcription. Recurring themes, which acted as background to the detailed discourse analysis, were identified. These were used to shed light on the complexity of the doctor-patient consultation and the communicative demands it placed on candidates (14).

\section{Results}

Description of candidates: Four of the 179 candiclates were excluded, as their ethnicity was undeclared. Table 1 gives the ethnicity, gender and age of the 
remaining 175 students. Seventy eight $(42 \%)$ were from ethnic minorities. All but two candidates had received secondary school education in the UK.

\section{Quantitative analysis of results}

Table 2 gives mean scores (with T value and statistical significance) for candidates grouped by efhnicity (WM or EM) for total OSCE performance, communication, practical, clinical, long case and study stations. Mean performance on communication stations was significantly higher for WM candidates on both day $1072.3 \pm 5.5 \%$ WM, 67.0 $56.8 \% \mathrm{EM}, \mathrm{p}=0.001)$ and day $2(69.5 \pm 6.3 \% \mathrm{WM}, 65.2 \pm 6.6 \% \mathrm{EM}, \mathrm{p}=0$ 003). The Cronbach alpha reliability of the OSCE was 0.74 and 0.76 on days 1 and 2 respectively.

\section{Qualitative analysis}

Forty nine $(13.7 \%)$ of the wideo recorded interactions were lost due to technical faults. There were no explicit examples of total communication breakdown or of discriminatory behaviour in the remaining 309 interactions. Neither SPs nor candidates showed, through talk or bodily movements, any expression identifiable as a negative response to the other's ethnicity or race.

Twenty eight $(9.1 \%)$ interactions, representing a range of scores from high to low and including students from both WM and EM groups, were transcribed for detailed discourse analysis. Two main findings emerged.

1: Candidates created very different interactional climates. Students receiving high grades were relatively empathetic, responsive and persuasive, building a joint problem-solving tramework with the patient. Conversely, some failed to build this framework, displayed various distancing moves in relation to patients and were given low grades by both examiners and simulated patients (15). Both WM and EM candidates lailed to create this interactive framework (Appendix 1). There were relatively more male EM candidates in this category: Fifteen (12 male) of the 22 scoring below minimum competence were EM candidates. In these instances there were no obvious cultural and linguistic differences, although these candidates were more likely to have pronunciation, word stress and intonation influenced by their heritage language.

2: Instances were found where the examiner gave top marks but the ethnic minority SP gave a lower mark. These candidates tended to use a style in which explicit guidance is deferred, there is more talk about the nature of the consultation and more talk about talk e.g. 'But first l'd like to know a little more about you'. (Appendix 2). 


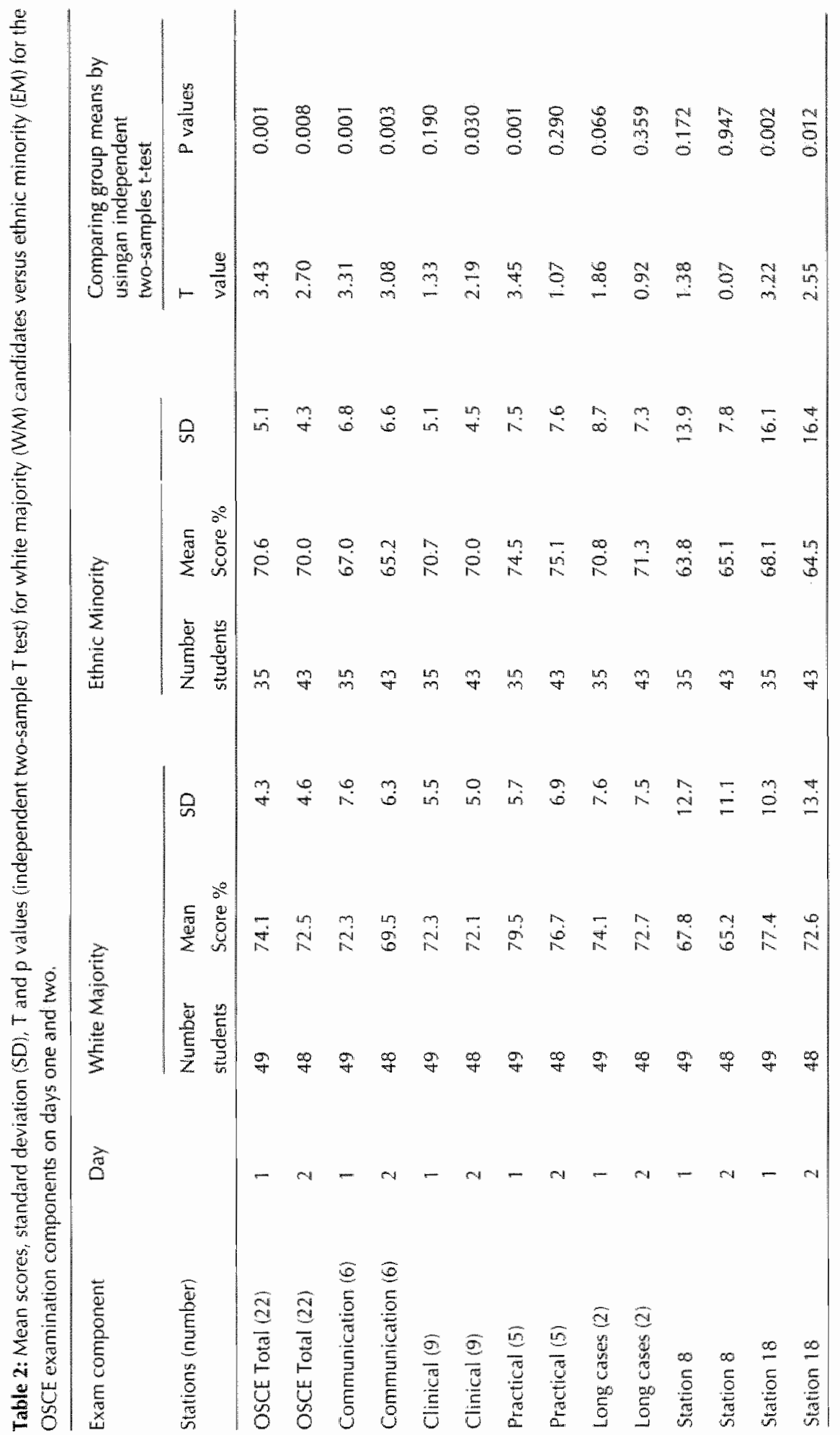


Athough this style fitted well with the white examiners' textbook patient centred preconcepulions, it was not rated so highly by some ethric minority SPs.

\section{Discussion}

This study has highlighted differences in mean performance of EM candidates within communication stations in our finall year OSCE. Although we saw no obvious evidence of communication breakdowns or discriminatory judgements, two subile differences emerged: a particularly poor communicative style which may have distanced some EM candidates from the SP (15) and instances where the examiner's assumptions did not appear to match the SP's expectations.

We do not want to claim too much from either of these two points: It would be dangerous to reify ethnicity and assume problems and differences in communicative style on the basis of an individual's ethnicity alone. Similarly, our comments on the differences between examiners and EM simulated patients are speculative and need further investigation. In combination, however, these two factors may account for at least some of the differences in the ratings of white and EM candidates.

The 'distancing' style of some candidates reflects a medical model of consultation rather than a more social one preferred by examiners. Why might EM candidates be relatively more likely than white candidates to use this style? One reason may be that a medical model is less demanding of communication skills and it may also be perceived as the appropriate model. In this case, differences in motivation and learning styles (16) also need to be considered. So a number of complex factors, communication styles, walues and ways of learning may all be important and may be related to the ways in which students are socialised into medical school culture.

Students who live outside the medical school and have networks of family and friends where there are quite different communicative experiences from those in the university (17) may have been less exposed to the informal and social talk around medicine occurring in institutionallife (18). They may have less opportunity to tume into the current institutional norms about what counts as a good consultation.

On the second issue, there is a case for developing a wider repertoire of communicative styles for setting OSCE stations. Skelton has raised important questions for educators in cross-cultural communication in medicine (13) but this needs to be addressed at the local level, for example, by examiners working with a range of 
non-traditional candidates and ethnic minority SPs to build up a wider repertoire of stylles sensitive to the diverse backgrounds of SPS.

Institutions may not be aware of hidden processes that reward some candidates and penalise others in the final examinations. It is, therefore, important to address issues of diversity in test construction and implementation if we are to satisfy ourselves that the assessment procedures do not disadvantage EM candidates. 


\section{References}

1. MCManus IC, Richards P. Winder BC, Sproston KA. Final examination performance of medical students from different ethric minorities. Med Educ 1996; 30: 195-200.

2. Dilliner L. Manchester lackles failure rate of Asian students. BM/ 1995; 310: 209.

3. Wakeford $R$, Faroogi $A$, Rashid A, Southgate L. Does the MRCCP examination discriminate against Asian doctors? BM/ 1992; 305: 92-4.

4. Jolly $B C$, Cohen $R$, Rothman $A$, Ross J. Graduates of foreign medical schools: demographic and personal predictors of success on an OSCE-format internship programme entrance examination. In Proceedings of the twenty seventh annual conference of the Association of American Medical Colleges 1988; pp234-9.

5. Smith R. Prejudice against doctors and students from ethric minorities (Editorial). BMJ 1987:294:328-9.

6. Mckenzie KJ. Racial discrimination in medicine (Editorial). BMI 1995; $310: 478$-9.

7. Roberts $C$, Sarangi S, Southgate $L$, Wakeford $R$, Wass V. Oral examinations - equal opportunities, ethnicity, and fairness in the MRCGP. BMJ 2000; 320:370-4.

8. Catto $G$. Education, education, education. BMJ Classified 23rd June 2001; pp 2-3.

9. Fowell SL, Maudsley G, Maguire P, Leinster SJ, Bligh J. Student assessment in undergradwate medical education in the United Kingdom. Med Educ 2000; 34 suppl 1: 1-49.

10. Wass V, Vleuten van der $C$, shatzer J, Jones R. Assessment of clinical competence. Lancet $2001 ; 357: 945-9$.

11. Vleuten CPM van der, Swanson DB. Assessment of clinical skills with standardised patients: State of the Art. Teach Learn Med 1990; 2:58-76.

12. Colliver, JA, Verhulst SI. Williams, RG, Norcini JI. Reliability of performance on standardised patient cases: A comparison of consistency measures based on generalizabillity theory. Teach Learn Med 1989; 1:31-7.

13. Skelton JR, Kail J, Loudon RF. Cross-cultural communication in medicine: questions for educators. Med Educ 2001; 35: $257-61$.

14. Erickson F. and Shultz J. 1982. The Counsellor as Gatekeeper: Sociall Interaction in Interviews. London: Academic Press.

15. Roberts C, Wass V, Jones R, Sarangi S, Gillett A. A discourse analysis study of "good" and "poor" communication in an OSCE: A proposed new framework for teaching students. Med Educ 2003; $326: 800-3$.

16. McManus IC, Richards P, Winder BC, Sproston K.A. Clinical experience, performance in final examinations, and leaming style in medical students: prospective study. BMJ 1998; $316: 345-50$.

17. Gumperz 1. 'A discussion with John Gumperz' in Eerdmans S, Previgagno $C$ and Thibault, P(eds) Discussing Communication Analysis 1 fohn Gumperz. 1997 Lausanne. Beta Press.

18. Atkinson P. Medical Talk and Medical Work: The Liturgy of the Clinic. London and Thousand Oaks 1995: CA: Sage Publications. 


\section{Appendix one:}

\section{A Framework for good and poor communicative styles}

The framework for communicative style consisted of four levels:

1: Performance factors. These included clarity, slips of the tongue, hesitations, voice quality and aspects of non-verbal communication.

2. The design of questions and responses. For example, the ways in which candidates showed that the patient's problem needed to be jointly managed, or the ways in which candidates were sensitive to the need to save the patient's face; or by contrast the negative labelling of the candidate of the use of 'trained' empathy.

3: The overall thematic staging of the consultation. For example, a candidate who had to resist giving a methadone script to a drug addict managed the consultation so as not to either give in or nefuse too early on; or, by contrast, a candidate shifting rapidly from one topic to another creating a 'bumpy ride' for the simulated patient and preventing him or her from following the candidate's line of reasoning.

4: Ideological positioning of the candidate. For example, how much to rely on personal authority and how much on medical authority.

Although technically competent in English, there were a small number of malle, ethnic minority candidates whose low grades were the result of subtle differences from the majority in their communicative style. The following example is from a candidate taking a sexual history from a young Muslim student (station 18 day 1 ), who received the lowest grade given by any simulated patient and who was failed by the examiner:

\section{Transcript}

can: 1: right erm let me just ask you some (.) er questions about (.) er the encounter with

2: this gentleman (.) erm (1.5) is he a regular partner or

act: $\quad 3$ :no it's complete one it's my first time lyeahl (.) because l come from a traditional 4: Muslim culture

can: 5iright

act: $\quad$ 6: er we don't have boyfriends in our culture.

can: $7:$ right

act: $\quad$ 8: erm (..) ljust (..) (breath out) (..) just (.) feel really terrible about it

can: 9: ok (.) erm (2.0) did you use protection at all

act: 10: no (..) it happened really quickly

can: 11: you didnt use any form of contraception

act: 12: (shakes head)) 
02:46.00 minutes

can: 13: ok and e-what type of erm (..) sex did you have was it er penetrative (.) waginal 14: sex

act: 15: ll just had sexual intercourse

can: 16: you had full sexual intercourse

act: $17:($ (nods) $)$

can: 18: right (.) did you have any (1.0) anal intercourse or oral (.) sex

act: 19: no

can: 20: right ok erm (5.5) can l just ask you a few (.) other questions when was your last 21 : period

act: $\quad 22$ : er it started yesterday

can: 23 : it started yesterday (.) right and have you had a cervical smear before at all

act: 24: no

can: 25: right erm (.) have you ever ha-been pregnant at all

act: $26:$ no

can: 27:right ok (1.0) erm (6.0) did (.) this patient have any er overt signs of any sexual

28: disease did he have any rashes at all or

act: 29 : sorry

can: $\quad 30:$ did the (.) did the partner that you had sex = with did he have =

act: $\quad 31:=$ yeah $=$

can: 32: any (.) sort of signs of (.) sexually transmitted diseases

$02: 47: 00$

act: $\quad 33:($ shakes head)

can: $34:$ any rashes or

act: 35 : no don't think so

can: 36: discharge (.) have you yourself had any discharges at all

act: $\quad 37:$ no

can: 38: any erm (.) irritation down there

act: $39:$ no

can: 40: any pain when you're passing water

act: 41 : no

can: 42: erm (..) any blood in your urine

act: $43:$ no

cam: 44: em (.) has your urine been offensive at all

act: 45: what do you mean

can: 46: has it been smelly at all

act: $47:$ no

can: 48: erm (.) and (.) do you have this (.) increase (.) do you have an increased need to (.) go (.) to the (.) hoo 
act:

can:

act:

There are several reasons why both role-player and examiner gave this candidate a very low grade. First of all, he staged these opening moments of the encounter from a perspective of physical medicine. The first crucial moment occurred at lines $6-8$ when the patient explained that she felt 'really terrible about it'. The candidate acknowledged this only with 'ok" and then proceeded to ask her about protection and the type of sex she had. This led to a protracted linear phase in which the patient gave no more than minimal responses. This is in contrast to lines $3-12$ in which she offered explanations and expressed her concems. These interrogatory sequences show the candidate going through a mental checklist rather than responding to her expressed needs and seeing the associations between her statem ments and her likely orientation to sexual activity.

The candidate's ideological positioning is also likely to have distanced him from the simulated patient. He derived his authority from his technical questioning and information on tests and test procedures rather than drawing on a more personal authority. In doing so, he categorised himself as a technical/medical person rather than as a social being relating to another. This meant that for example, questions about whether she had safe sex took precedence over responses to her feelings. And, his questioning of what type of sex (lines 13 -19) so close to her negative feelings, suggest that he was working with a schema that these sort of feelings must be associated with abnormal sex.

The staging and ideological positioning affected the turn by turn design of elicitations and responses. So, for example, from line 20 onwards he asked a series of slot - filling questions: 'have you had any...?' which closes down the possibility of a more descriptive conversational mode of interaction. At lines 33-44, there is a phase of rapid topic shifting which, combined with the slip of the tongue at line 27 , may have contributed to the patient's tailure to understand him at line 29. Similarly, this checklist mode tends to over-ride any careful listening by the candidate who wice in this phase of the consultation, at lines 8 and 31 , indicates that he has failed to pick up on information the patient had given him.

Finally, there are a number of performance factors which relate to the candidate's fluency, clarity, understandings and misunderstandings and voice quality which contributed to his low grade. These included a long pause at line 32 , the slip immediately after and his false pitching of medical register, for example, his difficulty in gauging the patient's medical knowledge (see line 48). These performance factors in combination with the design of elicitations and responses feed into the top-down 
elements of the interaction which themselves help to determine the turn by turn level.

The data from this failed candidate shows the uncomfortable moments, lost opportunities, inefficient use of time and 'trained' empathy characteristic of his communicative style in simulated consultations. This example highlights the fact that candidates need not only technical competence in English but also to be at ease with their means of communication so that they can use it flexibly in responding to patient need.

86 


\section{Appendix 2: \\ 'White' communicative style}

The following wo examples are both of white male candidates. The first one, on the alcohol station, received nearly full marks trom the examiner but a middle ranking mark from the simulated patient, a Chinese businessman (station 8 day 2 ). Here is a short extract from near the beginning:

\section{Transcript one}

1: can: Ive gat the test results here in front of me

2: act: $\mathrm{mm}$

3: can: ((clears throat)) (1.0) and there are a couple of abnormalities on them

4: act: $\mathrm{mm}$

5: can: erm but l'd like to know a litte bit more about you

6: act: $\quad m m==$

7: can: = because erm it's important that when we get any blood result that we

8: act: $\mathrm{mm}$

9: can: look at the whole patient $=$ and we $=$

10:act: $=m m=m m$

11:can: erm (.) put everything in context so we can make best sense of it

This is quite typical of the interaction in that this candidate did a great deal of context setting (or framing) and moved gradually towards the crucial question: 'Am I an alcoholic?". The examiner rated the quality of his talk very highty but the sinnulated patient, both within the consultation and in the mark he gave afterwards, was somewhat less happy. This may have been because of the candidate's communicative style: a great deal of framing, of leaving things open, delaying advice on specific treatment, going for the whole person, for patient understanding and commitment. He was offering talk, and in particular, talk at the thetorical level, but the simulated patient wanted action - in this case, specific treatment.

The second interaction shows a similar pattern (station 18 day 1 ). The candidate was given quite a good mark by the examiner but a rather mediocre one by the simulated patient (a young Muslim woman of South Asian background this extract is from nearly a third of the way through the consultation:

\section{Transcript 2}

1: can: okwell (1.5) well th- the first thing to say is that from from (..) from our point of wiew

2: we can do some tests and find out if you have got anything

3: act: yeah 
4. can: and (..) er obviously it's better to use protection in these situations (..) but $y$ - Imean

5: (.) being honest about it y- you (.) there's a high chance that you won't actually have

6. caught any any disease from him

$7:$ act: $\quad r i=g h t=$

8: can: $=$ and = wha- what's (.) what's worrying me slightly more is (.) is the fact that you reed

9: so bad aboul what you've done (2.0) er is there anyone you can talk to about this

at

10: home friends

The candidate took on a personally authoritative role, engaging with the simulated patient's feelings and giving her a lot of general reassurance. She, on the other hand, asked about the tests on several occasions and commented afterwards that he was a difficult candidate to mark. Again, the examiner rated the quality of his talk highly, whereas the patient wanted action - in this case, tests. So, in both examples, the 'white' authoritative, reassuring performance, where there is quite a lot of talk about talk (e.g. "being honest about it"; "its important that .... we look at the whole patient) was rated highly by the examiners but may be rather less patient-centred as far as the ethnic minority simulated patients are concerned. This suggests that even where there were no obvious cultural and linguistic differences displayed by ethnic minority simulated patients, there may be subtle differences in style and expectations. The traditionally 'good' candidate may need to adapt his or her style if there are cues from the patient that they have rather different expectations. 
Discussion 
This thesis has made a significant contribution to the evidence base needed to design assessment methodology; a fact acknowledged by international interest in the work $(1,2)$. The generalisability studies on the history taking $(\mathrm{HT})$ long case and orals demonstrate that, provided you test long enough, traditional test methodology has a place in high stakes examinations. Eight to ten observed long cases could achieve the same reliability as an $\mathrm{OSCE}_{i}$ as could four twenty minute structured orals each with two different examiners. This highlights the importance of content specificity. Provided assessments are structured to sample across sufficient different contexts, a reliable judgement can be achieved independent of the method used. The feasibility of delivering traditional examinations of suitable length is the key factor not the method. This opens new avenues to those designing and delivering assessments. Any method, old or new, has potential as long as content specificity issues are adequately addressed.

Similarly composite final examinations, designed to cover a wide range of competencies, can achieve high stakes reliability provided the components are carefully balanced to ensure content validity and there is parity between items and test length. The imbalance in reliability we demonstrated stresses once more the importance of designing high stakes examinations to sample content broadly. Discrepancies can also result if allowance is not made for the number of items per length of testing time. In this study the MCQ, with a large number of items compared to the essay paper of similar length, carried far more weight. The study demonstrates how crucial it is to ensure that the examination's purpose has absolute clarity and transparency. This is essential to the planning and construction of assessments. If establishing competency in practical clinical skills is the prime focus of the examination, measures must be taken to ensure the knowledge component does not dominate.

Further interesting questions are raised on the use of real versus standardised patients. The key difference between the long case and the OSCE was the unstandardised random selection of the patients. Standardised simulations do have great advantages. Real patients can be a liability both in terms of recruitment and performance on the day (3). Simulation enables accurate blueprinting of the content of the test but requires a high level of training and resource. Through comparing the long case along side the OSCE, these studies suggest that efforts to standardise encounters, and not use real patients, may lead to relatively small gains. The overall priority in test design is to ensure that sufficient encounters are assessed to address content specificity.

Traditionally the long case examination was based on a single randomly selected patient. This failed to address content specificity or achieve equivalent challenge across a cohort of candidates. How much has the move to set objective clinical standardised examinations (OSCEs) solved the problem? The final study, centred on 
communication stations in the OSCE, emphasised that these examinations are not as objective as their title suggests. Careful test construction is required to address issues of diversity in both standardised patients and candidates when both writing stations and implementing the examination. These findings are highly relevant in the current educational climate where we encounter increasing ethnic diversity of medical students within a single institution, escalating international movement of doctors and widening diversity within our society.

The studies do have some limitations. These pertain mainly to the restrictions of working within an existing examination framework. Modifications were possible to establish the changes needed to address the research questions i.e. the inclusion of two, rather than one, HT long cases. However the model used was not identical to that of the traditional long case format as the physical examination component had been excluded. Furthermore imposing observation and marking schedules moved the long case to some extent into an OSCE framework. It was impossible to avoid this. The examination board demonstrated great generosity in allowing the test to be extended to two cases in the first place and compromise was necessary. Two basic principles key to the long case were in place. Real, unstandardised patients were recruited in the traditional way and were allocated randomly. The unscripted free flow question format for the presentation was maintained. Much of the long case tradition was in place. The key aim of studying performance across unstandardised real patients selected at random and ensuring variation in complexity was achieved. The element of chance intrinsic to traditional examinations was present.

Internationally examinations are undergoing major review as the philosophy underpinning assessment methodology is challenged (4). The change is not spontaneous. Over the past decade there have been forces, both political and edlucational, driving a new approach. The key findings of this thesis (Box 1) are very relevant to these developments.

\section{Box 1: Summary of thesis findings relevant to change in assessment methodology}

- A variety of methods is needed to test clinical competence comprehensively

- Careful weighting of tests is essential for the outcome to reflect the purpose

- Testing time is of paramount importance to sample a broad clinical contexi

- All test methods can achieve high stakes reliability if the content is sufficient

- Standardisation using simulations is not crucial. Real patients have a role

- Objective structured examinations do not guarantee objective ludgements 
To understand how these conclusions inform the design of new assessment methodologies they need to be reviewed in the light of the forces promoting change. Increasing international focus on professional accountability has been a major political pressure. There is now much more social awareness that doctors should be fully accountable to their patients. Highly publicised fallures in medical practice, such as the Shipman report in the UK (5), have threatened public confidence (6). Testing written theoretical knowledge alone is not enough. Clinical competency must be robustly measured to confirm doctors are "fit for purpose" and have proficient clinical skills at a level of expertise appropriate to their practice. This has led to a new approach. There has been increasing pressure to assess doctors in the work place not the examination hall.

In the UK, for instance, the General Medical Council responded to public pressure by instigating the development of assessment processes for doctors whose poor performance was a cause for concern (7). This introduced a different perspective for assessment clesign. It became a "package" rather than a composite examination. Methodologies triangulating evidence from the workplace with more traditional examination formats (a knowledge and clinical skills test) have been developed. This work highlighted the need to carefully weigh the strengths and weaknesses of different methodologies. The aim was to ensure a critical judgement on the doctor's fitness to practise which could be defended against legal challenge. Such stakes are high. The challenge is similar to that of the composite finals examination where the components need to be carefully weighted to make an equally important judgement of whether the student was competent to graduate. In contrast the new assessment methodology depends on the triangulation of evidence rather than psychometrically combining examination results. The goal remains similar; that is to produce an assessment package which is appropriately weighted to the judgements being made and which mirrors the educational intents of the programme. Careful research of such packages is now needed, as the paper on composite final examination reliability illustrates, to establish whether these assessments actually achieve what they set out to achieve. In the face of political pressure, this could so easily be overlooked. We need to strive to ensure there new "assessment packages" become truly evidence based.

New educational philosophy is also driving change; fortunately in a similar direction. This thesis should be reviewed in the light of this. There is a move away from defining the process of learning and an increasing focus on measuring achievement. Both undergraduate and post graduate curricula are being framed as intended competency outcomes rather than the more traditional learning objectives. An example in the United Kingdom is the curriculum for the Modernising Medical Careers two year foundation programme (8). The aim is now to assess "performance"; the apex of Miller's triangle (9) as outlined in chapter two. 
Assessing a doctor in the workplace has become the Holy Grail. Reality, supported by the evidence from this thesis, is now dawning. It is no longer necessary to base assessments on highly reliable examinations alone. There is now the opportunity to collate and triangulate evidence gathered from the worlkplace using different methadologies. This enables progressive sampling overtime across a broad range of clinical contexts (10). The more traditional methods, such as the long case and orals, can be resurrected.

There are major advantages to these changes. Assessments can become more integrated. The behaviourist knowledge, skills and attitudes approach to the testing of learning outcomes is undoubtedly flawed (11). As the study on the composite nature of the medical school finals examination showed (chapter 3), the assumption that each trait can be assessed in isolation by a single method is a fallacy. All are intertwined. There is little point in awarding full marks for communicating bad news if, through faulty knowledge, the student has given the wrong news! The knowledge component is as important as the skill. Neither can be assessed in isolation. In addition competency based curricula can be harnessed in the workplace to enable those in training to be judged as and when they become competent. They can progress at their own intrinsic rate unhindered by the examination process $(8,10)$. Finally the educational impact of the assessments can be enhanced. Tests can be designed to lead education $(4,12,13)$. Tasks set in workplace can be planned and balanced to provide an appropriate drive to learning.

The findings of this thesis are very relevant to these changes. Traditional long cases and orals offer the advantage of a more integrated approach adaptable to the workplace where real patients abound in an authentic clinical context. We have demonstrated that these methods are potentially reliable provided sufficient sampling is ensured across a range of different cases. Logistically organising a series of cases, even over time, remains difficult. Hamdy et al in Bahrain recently demonstrated that a three hour examination of four 45 minute observed long cases had good reliability (14). Real patients selected from a predetermined blueprint of common diseases were used. The study provides evidence that a long case examination can be feasible and prove robust. However the lask of setting such examinations remains daunting for most institutions.

It is now pertinent to take a step back and explore the development of assessment methodology $(4,10)$. Can the more traditional methods be adapted to a feasible testing format to ensure a more integrated approach than that offered by the OSCE? The long case could be employed longitudinally and more formatively in the work place. New tools under development for the workplace are based on these traditional approaches. The "Mini CEX" format (15), introduced in the USA, is essentially a modification of an observed long case in the clinical setting. The method 
takes "snapshots" of the integrated assessment by focusing on one of a range of predetermined areas e.g. observation of history taking, the physical examination or the management of the case but not the entire process. Our findings both that observation increased the validity of the long case (chapter 5) and that, if a range of cases are used; the method can be reliable (chapter 4), support this approach. Furthermore it is emerging that less than ten cases may be enough for a reliable judgement of clinical competency to be made (chapter 4). Durning et al report acceptable reliability across seven such real patient mini-CEX cases (16). This confirms our finding (chapter 4) that eight to ten HT long cases can be reliable and solves some of the feasibility problems.

These findings continue to challenge the past assumption that standardisation of cases is essential to a reliable assessment of clinical competence. A remaining doubt is whether a sufficient number of independent judgements can be achieved in the workplace. This is an important issue. Assessors reach judgements rapidly and are unlikely to change their minds on ensuing cases (17). There is a tendency to overrate performance in the one to one workplace assessment situation (18). Evidence to date suggests achieving a range of independent judgements may be challenging. Careful planning of both the clinical content and range of assessors supporting a workplace based assessment package will be essential if such assessments are to achieve high stakes reliability. However it is clear that the use of real patients to support more integrated assessments need not be abandoned.

Other possible modifications of the long case to find more feasible formats may well be the way forward. The mini CEX within an OSCE type examination or a series of formally judged long cases across a training programme are both possibilities to be further explored. Similarly the use of orals across a series of cases may well be considered. In the UK, the assessment methods being set in place for Foundation doctors on their first two years post graduation, are all workplace based (8). One proposed method is case based discussions where doctors will present and discuss cases with an education supervisor. This is essentially an adaptation of the oral.

As these new assessment programmes evolve, research is essential to establish not only their reliability but also their validity. We must take a critical look at these new lests. Concerns have been raised over the objectivity and validity of the OSCE (19) yet there is little work to date on their valictity compared to studies of their relliability. In a recent study Simpson has demonstrated the relevance of validity studies (20) by demonstrating that the key purpose of a postgraduate oral examination, the candidates ability to reach decisions, was not always achieved. Understanding the validity of the new methods will be crucial. Studying the content validity of work place assessments such as the mini CEX will be important. How will we ensure in ad 
hoc testing across various attachments that a comprehensive range of both clinical context and skills is addressed?

The focus on competency-based outcomes is the major force currently driving change in assessment, Will this lead to more integrated and authentic assessment? There are genuine fears that this move negates the contribution made by length of clinical experience to the development of clinical competency (21). There is little educational evidence to support the move to outcome based curricula (22) and increasing concern that the professionalism of practice, i.e. the higher order metacognitive levels of performance and understanding, are not being assessed $(23,24)$. Our study of ethnic minority performance in OSCEs (chapter 7) raised further key questions. Simulations were used to assess cross cultural communication but it proved difficult to portray consistently authentic interactions particularly those requiring communication with patients whose English was limited. More work is needed to look at the authenticity of simulation within the complexities of our current social context and compare the use of real versus standardised patients in the achievement of a truly integrated assessment of clinical expertise.

In conclusion the overwhelming message of this thesis is that "context in clinical competence testing rules over all". These studies show that it is not the test format that matters as much as the test content i.e. as long as the examination samples widely enough any format has potential as a high stakes assessment. A combination of assessment methods needs to be used as no single method is either flawless or able to cover all aspects of clinical competency. The trait model of approaching assessment expressed as domains of knowledge, skilis and attitudes can be too simplistic. Indeed we need to be cautious when thinking in terms of behaviourist traits as these tend to atomise the process. The traditional assessment methods, such as the long case, use a more integrated process and should not be discanded. We need more research into designing and validating longitudinal assessments which include these integrated methods in a formative purposive way. Professional interaction with real patients is essential to the development of clinical expertise. To ensure appropriate learning assessment needs to mirror this.

Flexner's wisdom ultimately prevails; provided a single word of modification is added: "There is only one sort of licensing test that is significant i.e a lest that ascer" tains the practical ability of the students, confronting a SERIES of concrete cases, to collect all the relevant data and to suggest the positive procedures applicable to the conditions disclosed." (1). 


\section{References}

1. Nontan $C$. The long case versus objective structured clinical examinations. BM 2002; $324: 748-9$.

2. Norcin ll, The validity of long cases. Med Educ 2001; 35:135-7.

3. Sayer M, Bowman D, Evans D, Wessier $A$, Wood D. Use of patients in professional medicatexaminations: current UK practice and the ethico-legal Mmplications for medical education. BMI 2002; 324:404 -7.

4. Veuten CPM van der, Schuwirth L. Assessing professional competence: from methods to programmes. Med Educ 2005; 39;309:17

5. The Shipman Inquiry www the-shipman-inquiry.org.uk

6. Smitt R. All changed, changed utterly. BMI 1998; 316:1917.8

7. Southgate L, Cox J, David T, Hatch D, Howes A, Johnson N. The Ceneral Medical Council's Performance Procedures: Peer review of performance in the workplace. Med Educ $2001 ; 35: 9-19$.

8. Modernising Medical Careers 2005 www. mmc nhis.uth

9. Millet GE. The assessment of clinical skills/competence/performance. Acad Med 1990; 65:563-7

10. Swanwick $T$, Chana N. Workplace assessment for licensing in general practice. BJGP $2005 ; 55: 461-7$

11. Schuwirth L, Vleuten van der CPM. Changing education, changing assessment, changing research? Med Educ 2004; 38:805-12

12. Campion P, Foulkes I, Neighbour $R$, Tate P. Patient centredness in the MRCGP video examination: analysis of a large cohort. BMJ 2002; 325:691-2

13. Wakeford R, Southgate L. Postgraduate medical education: modifying trainees' study approaches by changing the examination. Teach Learn Med 1992; 4:210-3.

14. Hamdy H, Prasad K, Williams R, Salim FA. Reliability and validity of the direct observation clinical encounter examination (DOCEE). Med EduC 2003; 37:205-12.

35. Norcini H, Blank $L L$, Anold GK, Kimball HR. The mini-CEX \{clinical evaluation exercise): a preliminary investigation. Ann Intern Med 1995; 123:795-9

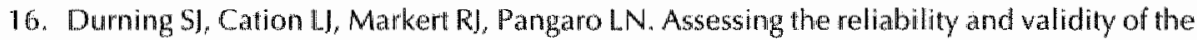
Mini Clinical Evaluation Fxercise for Internal Medicine residency training. Acad. Med. $2002 ; 77.900-4$

17. Swanson DB, Noman GR, Linn RL Performance-based assessment: Lessons learnt from the health protessions. Educational Researcher 1995; $24(5): 5411$.

18. Williams RG, Klamen DA, McGaghie WC. Cognitive, social and environmental sources of bias in clinical performance ratings. Teach Learn Med 2003; 15:270-92

19. Hodges B. Validity and the OSCE. Medlical Teacher 2003;25:250 4

20. Simpson RG, Ballard KD. What is being assessed in the MRCGP oral examination? A qualitative study. BJCP 2005; 55:430-6

21. Talbot M. Monkey see, monkey do: a critique of the competency model in graduate medical education. Med Educ. 2004; 38:587-92

22. Rees CE. The problem with outcomes-based curricula in medical education: insights from educational theory. Med Educ 2004; 38:593-8

23. Schuwirth LWT, Vleuten CPM van der. The use of clinical simulations in assessment. Med Educ 2003; 37 (suppl 1): 65-71 
24. Wass $V$. "Is competency based training and assessment the way forward?" BMI Career Focus 2004: 329:220-1 


\section{Summary}




\section{Chapter 1: Background}

There is increasing pressure for professional accountability and assurance to the public that doctors are clinically competent to practise. Medical schools in the UK, in order to deliver more relliable examinations which test broadly across the curriculum, have moved away from traditional assessments such as long cases and orals to more "atomised" formats such as the Objective Structured Clinical Examinations (OSCEs) and Multiple Choice Questions. Yet this change has occurred in the face of a paucity of published psychometric data on traditional methods. This thesis studies a final examination in the process of change from old methodology to new and seizes the opportunity to investigate, the psychometrics of the traditional formats in more depth, before their demise. The key research question overarching the thesis is "Have we become too "atomistic" in our approach to assessing clinical competence? Are we justified in abandoning the more integrated traditional high stakes examinations formats, in particular the long case, too early without either attempting to improve their validity or measuring their reliability?"

\section{Chapter 2}

A review of the important principles underpinning the assessment of clinical competence, which aimed to achieve an international perspective, introduces the thesis. The importance of carefully blueprinting the content of examinations against the curricula, setting appropriate standards, balancing the validity of the tests against their reliability and weighing the formative and summative functions of the assessment are outlined. The paper concludes that current examination formats tend to focus too heavily on knowledge based competencies and further research into the format and reliability of composite medical examinations is important.

\section{Chapter 3}

A battery of tests is often used to measure all the attributes of clinical competence. The final medical school examination under study focused on assessing competency traits: "knowledge, skills and attitudes". It consisted of three written papers, an OSCE and two history taking long cases. The initial research question asked "How reliable is a composite final year undergraduate examination?" Using multivariate generalisability theory, variances in test length and composition were accounted for and an index of overall reliability was obtained. The results highlighted that careful structuring of papers to balance the length and format of individual tests is crucial to ensure acceptable and meaningful reliability is achieved.

\section{Chapter 4}

Previous studies had looked at the inter-rater reliability of long cases but there was little data on inter-case reliability. By including two modified history taking (HT) 
long cases with real patients alongside the OSCE, generalisability theory was used to answer the question "How many long cases would be needed to achieve a reliable high stakes test?" It was concluded that eight to ten thirty minute HT long cases would achieve reliability consistent with a high stakes examination. Thus provided sufficient testing time and real patients were avallable to cover a range of content specificity, the long case could not be abandoned for reasons of reliability alone. Length of testing time rather than the method used appears to reign supreme.

\section{Chapter 5}

In the traditional long case format only the presentation of the patient is marked and the interaction between patients and student is not observed. A further modification of the examination was set in place to test the hypothesis that if the patient-student interaction was observed and graded a more valid assessment would result. Ratings of two examiners observing and marking the student taking the history were compared with the independent marks of two different examiners assessing the presentation. Ratings of observation and presentation contributed significantly and independently to the correlation with clinical competence, as judged from the candidates" OSCE scores. Observing the interaction proved worthwhile.

\section{Chapter 6}

A further research question arose. If extending testing time improved the reliability of long cases, would the same principle apply to traditional oral examinations? Generalisability theory was used to analyse the oral components of the Membership of the Royal College of General Practitioners examination. Although some attempt at improving the content of the orals had been made, examiners continued to use their own questions in the traditional way. The same principle held true. Extending testing time to four 20-minute orals, each with two examiners, or five orals, each with one examiner, resulted in predicted pass/fail reliabilities consistent with high stakes tests.

\section{Chapter 7}

Finally when weighing the advantages of the new approach of using simulations rather than real patients, we developed concerns that the use of simulations was not achieving true objectivity within the OSCE. We were concerned that, as ethnic minority students tended to perform less well in the OSCE, there was possible disadvantage either in the setting of the stations or the marking. Despite standardisation and temisation of communication skill stations in an OSCE was there still potential for bias in ratings? Interactions on four communication stations were videoed and analysed using qualitative discourse analysis. No examiner bias was seen but the research highlighted the importance of ensuring stations are carefully constructed so that ethnic minority candidates are not disadvantaged. 


\section{Conchusions}

These studies have shown that it is not the test format that matters as much as the test content i.e., as long as the examination samples widely enough, traditional formats have the same potential as new ones to provide reliable assessments of clinical competence. The trait model of approaching assessment expressed as domains of knowledge, skills and attitudes may be too simplistic and can create complicated tests which need careful design if the purpose of the test is to be achieved and bias avoided. Indeed we need to be cautious when thinking in terms of behaviourist traits as these tend to atomise the process.

No single method is flawless and the advantages of using standardised rather than real patients may not be as significant as was originally thought. The traditional assessment methods, such as the long case and orals, use a more integrated process and should not be discarded although the feasibility of using these within summative assessments is such that they have a more formative rather than summative role. The current move away from examinations towards more assessment in the workplace presents welcome opportunities to revisit and develop these test methodologies.

We need more research into designing and validating longitudinal assessments which use these integrated methods in a formative purposive way and which emphasise to students the educational importance of experience in interaction with patients. 
Samenvatting 


\section{Hoofdstuk 1 : Achtergrond}

Er wordt steeds meer druk uitgeoefend op artsen om verantwoording af te leggen voor hun klinisch handelen. Ook worden steeds vaker garanties gevraagd dat artsen competent zijn om hun beroep uit te oefenen. Gezien deze ontwikkeling, helben medische faculteiten gezocht naar methoden om klinische competentie betrouwbaar en gedurende het gehele curriculum te kunnen meten. Dit heeft ertoe geleid dat traditionele toetsmethoden, zoals 'long cases' en mondelinge examens, overboord zijn gezet en vervangen door 'geatomiseerde' toetsmethoden, zoals stationsexamens en meerkeuzetoetsen. Ten tijde van deze verandering waren er slechts weinig gepubliceerde gegevens over psychometrische eigenschappen van traditionele toetsmethoden beschikbaar.

Het in dit proefschrift beschreven onderzoek is uitgevoerd tijdens het overgangsproces van oude naar nieuwe toetsmethoden bij een bestaand afsluitend examen aan het eind van de basisartsopleiding. Dit overgangsproces is aangegrepen voor een diepgaand onderzoek van de psychometrische engenschappen van de traditionele toetsmethoden voordat ze definitief werden afgeschaft. De centrale onderzoeksvraag is: Is onze benadering van toetsing van klinische competentie te atomistisch geworden? Is het verdedigbaar om traditionele geïtegreerde toetsmethoden, zoals de 'long case', voor belangrijke examens voortijdig af te schaffen, zonder te onderzoeken of de validiteit verbeterd kan worden en de betrouwbaarheid vast te stellen?

\section{Hoofdstuk 2}

Als inleiding wordt, vanuit een internationale invalshoek, een overzicht gegeven wan de belangrijkste basisprincipes van toetsing van klinische competenties. Er wordt ingegaan op het belang van blauwdrukken om toetsing te laten aansluiten bij de curriculuminhoud, het vaststellen van beoordelingsnormen, het afstemmen van validiteit en betrouwbaarheid van toetsen en afwegingen ten aanzien van formatieve en summatieve toetsing. De conclusie is dat de huidige toetsmethoden te veel gericht zijn op competenties op basis van kennis en dat er onderzoek gedaan moet worden naar methoden en betrouwbaarheid van samengestelde examens in de geneeskundeopleiding.

\section{Hoofdstuk 3}

Vaak wordt een testbatterij gebruikt om alle aspecten van klinische competentie te meten. Het in dit hoofdstuk beschreven onderzoek betreft een afsluitend examen dat voornamelijk gericht is op toetsing van competentieaspecten: "kennis, vaardigheden en attitudes" "Het examen bestaat naast drie schriftelijke onderdelen uit een stationsexamen en twee "long cases", warbij studenten de anamnese afnemen bij een echte patiënt. De onderzoeksvraag is: "Hoe betrouwbaar is een afsluitend samengesteld examen in het laatste jaar van de basisartsopleiding?". Met behulp 
van multivariate generaliseerbaarheidstheorie zijn de effecten van wariatie in toetsduur en toetssamenstelling onderzocht en is een globale betrouwbarheidsindex opgesteld. Uit de resultaten blijkt dat afstemming van duur en vorm van afzonder lije toetsonderdelen een cruciale voorwaarde is voor acceptabele, zinvolle en betrouwbare toetsing.

\section{Hoofdstuk 4}

Aan de interbeoordelaarsbetrouwbaarheid van 'long cases' zijn verschillende onderzoeken gewijd, maar over intercasusbetrouwbaarheid is maar weinig bekend. Twee aangepaste 'long cases', waarbij studenten de anamnese afmemen bij echte patiënten zijn toegevoegd aan een stationsexamen. Vervolgens is met behulp van generaliseerbaarheidstheorie onderzocht hoeveel 'long cases' nodig zijn voor betrouwbare toetsing. De resultaten laten zien dat bij een examenduur van 8 tot 30 minuten de betrouwbaarheid acceptabel is voor een afsluitend examen. Het blijkt clus dat betrouwbaarheid onvoldoende aanleiding vormt om het traditionele examen af te schaffen, mits er genoeg toetstijd en echte patiënten beschikbaar zijn voor voldoende inhoudelijke variatie in de toets. Niet toetsmethode maar toetsduur blijkt van doorslaggevend belang.

\section{Hoofdstuk 5}

De beoordeling van de traditionele 'long case' is uitsluitend gebaseerd op de patiëntenpresentatie door de student, terwijl het student-patiëntcontact niet geobserveerd wordt. Een verdere aanpassing van het examen maakte het mogelijk om de hypothese te toetsen dat de validiteit van de beoordeling verbetert als het student-patiëntcontact geobserveerd en beoordeeld wordt. Het oordeel van wee examinatoren die de studenten tijdens de anamnese observeren en beorclelen, is vergeleken met het oordeel van twee verschillende examinatoren op basis van patiëntenpresentaties. Beide oordelen blijken een significante en onafhankelijke bijdrage te leveren aan de correlatie met de beoordeling van klinische competentie op basis van het stationsexamen. Hef blijkt dus zinvol om patièntencontacten te observeren.

\section{Hoofdlstuk 6}

Een andere onderzoeksvraag diende zich nu aan. Als een langere toetsdurur de betrouwbaarheid van 'long cases' vergroot, doet eenzelfde effect zich dan ook voor bij traditionele mondelinge examenvormen? Met behulp van generaliseerbaarheidstheorie zijn de mondelinge onderdelen van de toelatingstoets voor het Royal College of General Practitioners geanalyseerd. Ondanks pogingen om de inhoud van de mondelinge examens te verbeteren, hielden de examinatoren vast a an de gebruikelijke manier van examineren. De analyse laat inderclaad een vergelijkbaar effect zien als bij de 'long case'. Verlenging van het examen tot vier mondelinge 
toetsen van wintig minuten met wee examinatoren of tot vijf mondelinge toetsen met vij verschillende examinatoren leidt tot een voorspelde betrouwbaarheid die acceptabel is voor een belangrijk examen.

\section{Hoofdstuk 7}

Naar aanleiding van afweging van de voordelen bij de nieuwe toetsaanpak van simulaties en echte patiënten, rees de vraag of simulaties in het stationsexamen wel voldoende garantie bieden voor echte objectiviteit. Aanleiding tot bezorgdheid waren de minder goede prestaties van allochtone studenten. Deze vormden een aanwijzing dat er factoren in de setting van de stations of de beoordeling waren, die in het nadeel van deze studenten konden werken. Wordt de beoordeling van stations over communicatievaardigheden, ondanks standaardisatie en gedetailleerde beoordelingslijsten, negatief beïnvloed door vooroordeel? De interacties bij vier stations over communicatievaardigheden zijn op video opgenomen en onderzocht met behulp wan kwalitatieve tekstanalyse. Er werd geen vooroordeel bij de examinatoren waargenomen, maar de onderzoeksbevindingen onderstrepen het belang van uiterste zorgvuldigheid bij het ontwerpen van stations om effecten te voorkomen die nadelig kunnen zijn voor kandidaten van allochtone afkomst.

\section{Conclusies}

Dit proefschrift toont aan dat de toetsmethode van minder doorslaggevend belang is dan de toetsinhoud. Met andere woorden: bij een voldoende gevarieerde exameninhoud kan klinische competentie even betrouwbaar gemeten worden met traditionele als met nieuwe toetsvormen. Een model dat onderscheid maakt tussen toetsing van kennis, vaardigheden en attitude is wellicht te eenvoudig. Dit kan leiden tot ingewikkeld toetsen die zeer zorgvuldig samengesteld moeten worden om het beoogde toetsdoel te kunnen bereiken en vooroordeel uit te sluiten. Grote voorzichtigheid is geboden bij het denken in termen van gedragsmatige aspecten, omdat dit kan leiden tot geatomiseerde toetsprocedures.

Geen enkele toetsmethode is volmaakt en wellicht bieden gestandaardiseerde patiënten in vergelijking met echte patiẻnten minder grote voordelen dan aanvankelijk werd gedacht. Traditionele toetsmethoden, zoals 'long cases' en mondelinge examens, worden gekenmerkt door een geïntegreerde benadering. Afschaffing van deze examens lijkt ongewenst, ook als in aanmerking wordt genomen dat zij uit haalbaarheidsoverwegingen geschikter zijn voor formatieve dan voor summatieve beoordeling. De huidige tendens om traditionele toetsvormen te vervangen door beoordelingen in de praktijk biedt een uitstekende aanleiding om deze toetsmethoden te herontdekken en verder te ontwikkelen.

Ondlerzoek is nodig naar de ontwikkeling en validering van longitudinale geintegreerde beoordelingsmethoden voor formatieve doeleinden, die bovendien de leerzaamheid van contacten met echte patiënten kunnen benadrukken. 
Curriculum Vitae 
$\frac{9}{5}$ 


\section{Val Wass \\ BSc Hons, MRCP, FRCGP, MHPE, ILTM}

I was born on 140248 in Windsor, Berkshire UK. On qualifying from Guy's Hospital medical school (1966-72) my career started in clinical nephrology for ten years (1973-1983) before subsequently training in primary care. I was a partner in a general practice in Kent, UK for the following twelve years and became increasingly engaged in postgraduate medical education. As an examiner for the Royal College of Ceneral Practitioners (RCGP) and convenor for the oral component of the RCGP Membership Examination (1994-1999), I developed a strong interest in assessment.

In 1995 I moved to work on the undergraduate programme in the Academic Department of General Practice at the United Medical and Dental Schools of Guy's and St Thomas' Hospitals (UMDS), London. My increasing fascination with assessment led to a lead role in the development and delivery of clinical competency assessment across all five years of the medical school.

Research done during this period both at UMDS and at the RCGP formed the basis of this thesis. I remain indebted to the Dean of UMDS Professor Gwyn Williams and the convenor of the MRCGP, Dr Roger Neighbour, for their permission and support to undertake the studies.

I now lead on Community Based Medical Education at the Medical School in the University of Manchester 